\title{
The Stratigraphy of Mars
}

\author{
KENNETH L. TANAKA
}

\author{
U. S. Geological Survey, Flagstaff
}

\begin{abstract}
A detailed planetwide stratigraphy for Mars has been developed from global mapping based on Viking images and crater counting of geologic units. The original Noachian, Hesperian, and Amazonian Systems are divided into eight series corresponding to stratigraphic referents. Characteristic crater densities and material referents of each series are (1) Lower Noachian [N(16)] (number of craters $>16 \mathrm{~km}$ in diameter per $\left.\left.10^{6} \mathrm{~km}^{2}\right)>200\right]$ basement material; (2) Middle Noachian $[\mathrm{N}(16)=100-200]$ cratered terrain material; (3) Upper Noachian $[\mathrm{N}(16)=25-100 ; \mathrm{N}(5)=200-400]$ intercrater plains material; (4) Lower Hesperian $[N(5)=125-200]$ ridged plains material; (5) Upper Hesperian $[N(5)=67-125 ; N(2)=400-750]$ complex plains material; (6) Lower Amazonian [N(2) = 150-400] smooth plains material in southern Acidalia Planitia; (7) Middle Amazonian [N(2) = 40-150] lava flows in Amazonis Planitia; and (8) Upper Amazonian [N(2) $<40]$ flood-plain material in southern Elysium Planitia. Correlations between various crater size-frequency distributions of highland materials on the moon and Mars suggest that rocks of the Middle Noachian Series are about 3.92-3.85 b.y. old. Stratigraphic ages compiled for units and features of various origins show that volcanism, tectonism, and meteorite bombardment have generally decreased through Mars' geologic history. In recent time, surficial processes have dominated the formation and modification of rock units. The overall stratigraphy of Mars is complex, however, because of temporal and spatial variations in geologic activity.
\end{abstract}

\section{INTRODUCTION}

A new global geologic map series at 1:15,000,000 scale derived from Viking images has expanded and improved our knowledge of the geologic and stratigraphic framework of Mars. This series consists of three maps covering the following regions: the western equatorial region (lat $\pm 57^{\circ}$, long $0^{\circ}$ to $180^{\circ}$ [Scott and Tanaka, 1986]), the eastern equatorial region (lat $\pm 57^{\circ}$, long $180^{\circ}$ to $360^{\circ}$; R. Greeley and J. E. Guest, unpublished data, 1986), and the north and south polar regions (lat $> \pm 55^{\circ}$ [Tanaka and Scott, 1987]. This mapping, combined with previous studies and new crater counts, forms the basis for the most detailed formal representation of Martian geologic history to date. In this paper, I propose new stratigraphic series and epochs that form discrete stages into which the evolution of the planet's surface can be divided.

In an early study of the Martian surface, Soderblom et al. [1974] recognized four stratigraphic divisions: ancient eroded uplands, cratered (ridged) plains interpreted as volcanic, Elysium volcanic rocks, and Tharsis volcanic rocks. Formal geologic mapping of Mars began with a 1:5,000,000-scale map series based mainly on Mariner 9 images. Because of the varied quality and resolution of the images and the difference in mapping style among the workers, the stratigraphic classification systems that they developed were commonly inconsistent. Most authors used a qualitative approach to stratigraphic age by defining three, four, or five impact-crater degradation classes [e.g., Masursky et al., 1978; Wise, 1979; Moore, 1980; respectively]; some [Milton, 1974; Masursky et al., 1978; Wise, 1979] used craterdensity data to determine theoretical absolute ages from the cratering history models of Soderblom et al. [1974] and Neukum and Wise [1976].

A formalized stratigraphy was first presented in the 1:25,000,000-scale geologic map of Mars by Scott and Carr [1978]. Condit [1978] counted 4- to 10-km-diameter craters and used them, together with overlap relations and degradational

This paper is not subject to U. S. copyright. Published in 1986 by the American Geophysical Union.

Paper number 6B7240. appearance, to determine the relative ages of map units. These units were classified and placed in three stratigraphic systems: the Noachian System, characterized by rugged, heavily cratered material; the Hesperian System, whose base was defined as the base of the ridged plains material; and the Amazonian System, which included relatively smooth, moderately cratered plains materials and polar deposits. The names for these systems were selected from regions having representative and widespread exposures of the materials used as referents.

A new generation of local geologic maps of Mars at different scales were based on improved imagery acquired from the Viking orbiters [Scott et al., 1981; Dial, 1984; Scott and Tanaka, 1984; Witbeck and Underwood, 1984]. All of these workers followed the time-stratigraphic systems developed by Scott and Carr [1978]. The stratigraphic-system boundaries were defined by using densities of craters having diameters of 4-10 $\mathrm{km}$ [Greeley and Spudis, 1981] and 2, 5, and $16 \mathrm{~km}$ [Scott and Tanaka, 1984, 1986]. In addition, Gurnis [1981] obtained crater densities for broad terrain units, and many workers focused on local or regional geologic histories that provide crater-density data and stratigraphic relations.

The present study sets forth a new, Viking-based stratigraphy of Mars in which I (1) establish a more detailed chronostratigraphic classification system, (2) ascertain the crater densities and possible absolute ages of the chronostratigraphic units, (3) deduce relative ages of major geologic units and features, (4) present stratigraphic maps of the entire surface, and (5) summarize the planet's geologic history in order of epochs.

\section{Subdivision of Martian Chronostratigraphic UNITS}

The three-period, time-stratigraphic classification established by Scott and Carr [1978] is useful, widely recognized, and in no need of fundamental revision. Subdivision of the chronostratigraphic systems into series is now possible because of recent and ongoing work, particularly on the western region of Mars [Scott and Tanaka, 1986], and is necessary for detailed stratigraphic work. For simplicity and utility, series names are adapted from system names and qualified with "Upper," "Middle," and "Lower." Referents were picked on the basis of prior usage and recognition, established stratigraphic position, 
TABLE 1. Chronostratigraphic Series and Referents for Mars

\begin{tabular}{|c|c|}
\hline Series & Referent \\
\hline Upper Amazonian & $\begin{array}{l}\text { Flood-plain material, southern Elysium } \\
\text { Planitia }\end{array}$ \\
\hline $\begin{array}{l}\text { Middle Amazonian } \\
\text { Lower Amazonian }\end{array}$ & $\begin{array}{l}\text { Lava flows, Amazonis Planitia } \\
\text { Smooth plains material, Acidalia } \\
\text { Planitia }\end{array}$ \\
\hline Upper Hesperian & $\begin{array}{l}\text { Complex plains material, Vastitas } \\
\text { Borealis }\end{array}$ \\
\hline Lower Hesperian & $\begin{array}{l}\text { Ridged plains material, Hesperia } \\
\text { Planum }\end{array}$ \\
\hline Upper Noachian & $\begin{array}{l}\text { Intercrater plains material, east of } \\
\text { Argyre Planitia }\end{array}$ \\
\hline Middle Noachian & $\begin{array}{l}\text { Cratered terrain material, west of Hellas } \\
\text { Planitia }\end{array}$ \\
\hline Lower Noachian & $\begin{array}{l}\text { Basement material, Charitum and } \\
\text { Nereidum Montes }\end{array}$ \\
\hline
\end{tabular}

areal extent, degree of preservation, and, above all, representation of a distinctive geologic episode. In contrast to terrestrial rock units, the Martian units are largely defined by their surficial characteristics, and rock types are inferred. Also, recognition of vertical changes in the units and description of their bases generally are not possible. The newly proposed series and their referents and crater densities are formally described below (and summarized in Tables 1 and 2). Possible absolute ages for these series are discussed in a following section.

\section{Lower Noachian Series}

Recent mapping [Scott and Tanaka, 1986] distinguished stratigraphically lower "basement material" from the widespread cratered terrain material in many areas on Mars. Both of these materials are part of the Noachian System [Scott and Carr, 1978]. The basement material includes units previously mapped as "basin rim material" and "mountain material" belonging to the Noachian and Hesperian Systems [Scott and Carr, 1978]. The type area selected for the Lower Noachian Series consists of Nereidum and Charitum Montes, which form the uplifted rim material surrounding Argyre Planitia (Figure 1). The rim has an inside diameter of about $700 \mathrm{~km}$ and an outside diameter of about $1400 \mathrm{~km}$, and at most places it rises 1 to $2 \mathrm{~km}$ above the interior plain but less than $1 \mathrm{~km}$ above the surrounding plateau [ Wu et al., 1986]. The material is rugged, heavily cratered, and faulted, and it forms hills, ridges, and massifs that are generally aligned concentrically with Argyre Planitia. Some of the massifs and ridges of northern Charitum Montes appear similar in size to those within Valles Marineris that have relief of about 3 to $5 \mathrm{~km}$. Generally, rims of superposed impact craters are degraded and ejecta blankets are not recognized. Because of this degradation, crater densities are not reliable for relativeage comparison between materials of the Lower Noachian Series and units of other series; however, they appear to be useful in determining relative ages of the rock units within the series at different localities. One area of basement material at lat 280 $S$, long $101^{\circ}$ has relatively well preserved craters $[N(16)$ (number of craters $>16 \mathrm{~km}$ in diameter per $10^{6} \mathrm{~km}^{2}$ ) $=294 \pm 81$. The lowermost part of this basement material is not exposed and its top is embayed by Middle Noachian cratered terrain material.

Other outcrops of material embayed by this cratered terrain material form basin rims that surround Hellas, Argyre, and Isidis Planitiae and form Promethei Rupes (south polar basin), as well as isolated massifs and ridges, which are mostly in the western part of Mars [Scott and King, 1984]. Material of similar position may also be exposed at the base of deep scarps, such as those within Valles Marineris. Possibly the material of the Lower Noachian Series represents upper parts of the primitive crust of Mars formed by solidification of a primordial, molten surface and bombarded by large planetesimal-size objects.

\section{Middle Noachian Series}

The Middle Noachian Series consists of cratered terrain material that characterizes most of the rugged highland terrain and scattered cratered terrain remnants in the northern plains of Mars. Much of this material was mapped as "hilly and cratered" or "cratered plateau" materials by Scott and Corr [1978] and was recently remapped as the "cratered unit of the plateau sequence" [Scott and Tanaka, 1986]. This rock unit is the most widespread of the Noachian System. The designation of the Noachian System was originally based on material in the Noachis area west of the Hellas impact structure. This area (lat $40^{\circ} \mathrm{S}$, long $320^{\circ}$ to $345^{\circ}$ ) still appears to be the most typical of cratered terrain, and it is selected as the type area of the Middle Noachian Series. Most other highland regions are partly buried or more highly degraded. The region west of Syrtis Major Planum, although highly degraded, displays one of the highest densities of large impact craters and double-ring basins on Mars. In general, the cratered terrain has a rugged surface of moderately high relief, marked by secondary craters, channels, wrinkle ridges, and erosional scarps. The rock unit embays material of the Lower Noachian Series in many areas and in tum is overlain by intercrater plains material of the Upper Noachian Series.

TABLE 2. Crater-density Boundaries for Martian Series

\begin{tabular}{|c|c|c|c|c|c|}
\hline \multirow[t]{2}{*}{ Series } & \multicolumn{5}{|c|}{$\begin{array}{c}\text { Crater Density } \\
\left(\mathrm{N}=\text { no. craters }>(x) \mathrm{km} \text { diam. } / 10^{6} \mathrm{~km}^{2}\right)\end{array}$} \\
\hline & $N(1)$ & $N(2)$ & $\mathbf{N}(5)$ & $\mathbf{N}(16)$ & $N(4-10)$ \\
\hline $\begin{array}{l}\text { Upper Amazonian } \\
\text { Middle Amazonian } \\
\text { Lower Amazonian } \\
\text { Upper Hesperian } \\
\text { Lower Hesperian } \\
\text { Upper Noachian } \\
\text { Middle Noachian } \\
\text { Lower Noachian }\end{array}$ & $\begin{array}{c}<160 \\
160-600 \\
600-1600 \\
1600-3000 \\
3000-4800\end{array}$ & $\begin{array}{c}<40 \\
40-150 \\
150-400 \\
400-750 \\
750-1200\end{array}$ & $\begin{array}{c}<25 \\
25-67 \\
67-125 \\
125-200 \\
200-400 \\
>400\end{array}$ & $\begin{array}{c}<25 \\
25-100 \\
100-200 \\
>200\end{array}$ & $\begin{array}{c}<33 \\
33-88 \\
88-165 \\
165-260 \\
>260\end{array}$ \\
\hline
\end{tabular}

Crater densities for $\mathrm{N}(1)$ and $\mathrm{N}(4-10)$ are derived from $\mathrm{N}(2)$ and $\mathrm{N}(5)$ values based on the assumption of a -2 power-law size-frequency distribution. 

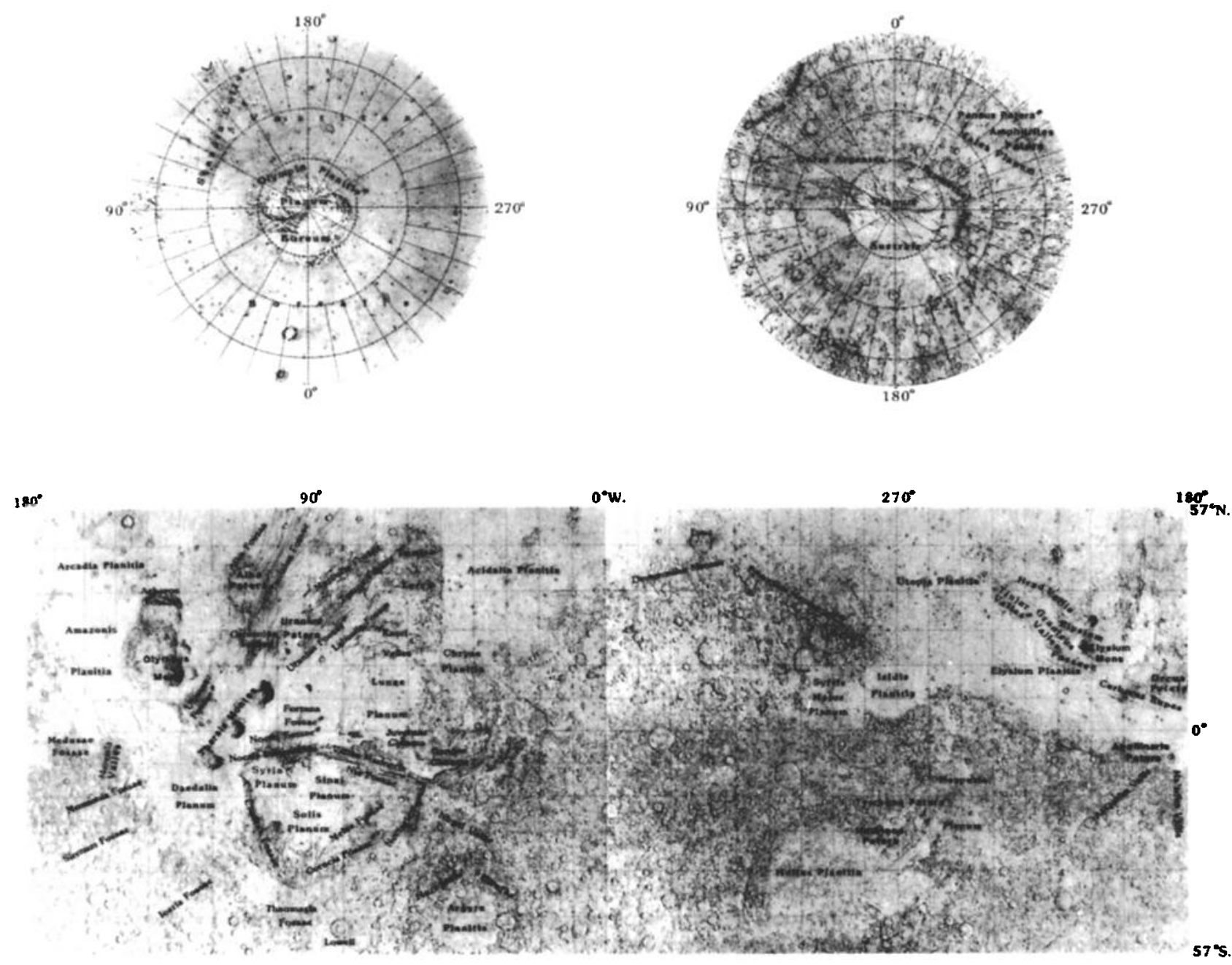

Fig. 1. Shaded-relief map of Mars showing geographic nomenclature used in this study; names followed by an asterisk are provisional [U.S. Geological Survey, 1985].

Densities of craters no more than a few kilometers in diameter on the cratered terrain material are about the same as those on the overlying intercrater plains material [Tanaka, 1985a] and thus are not helpful in relative-age determinations. However, large craters are more likely to be preserved and recognized and to be useful for correlation. As a standard, cumulative densities of craters larger in diameter than $16 \mathrm{~km}$ are used for correlation of materials of this series [Scott and Tanaka, 1986]. Although the relative stratigraphic positions among the Upper, Middle, and Lower Noachian are generally evident, the materials overlap in crater density from place to place.

\section{Upper Noachian Series}

The "cratered plateau material" was described by Scott and Carr [1978] as densely cratered but flat and smooth in intercrater areas. This rock unit was placed in the uppermost part of the Noachian System. Recent mapping by Scott and Tanaka [1986] shows the smooth intercrater areas as a separate unit (subdued cratered unit of the plateau sequence) that overlies the cratered terrain material. This distinction permits the designation of the Upper Noachian Series as represented by such intercrater plains material. The type area selected is east of the Argyre impact basin in the vicinity of lat $45^{\circ} \mathrm{S}$, long $15^{\circ}$. Here, many craters that are part of underlying cratered terrain material are partly buried by intercrater plains material. Smaller craters are commonly rimless and larger craters have low rims. Crater ejecta and floors are mostly buried. The intercrater plains surface is smoother than cratered terrain, but it is dotted by many small craters and locally cut by channels or marked by wrinkle ridges. Statistics for craters larger than about $5 \mathrm{~km}$ in diameter are fairly reliable for relative-age determinations (Table 3).

Intercrater plains material overlies and embays Middle Noachian cratered terrain material throughout the Martian highlands. In turn, it is locally overlain by other plains material that is smoother, less cratered, and commonly ridged. Preliminary work with Viking images [Scott and Tanaka, 1984] did not show these relations; however, new, more complete mapping [Scott and Tanaka, 1986] does show this stratigraphic distinction. The intercrater plains unit has few features that can be used to identify its origin; it may have multiple origins, such as lava flows, flood-plain deposits, and eolian fill.

\section{Lower Hesperian Series}

The Hesperian System was named for Hesperia Planum (Figure 1). The base of the system was delineated by the base of the "ridged plains material" [Scott and Carr, 1978]. This 
TABLE 3. Crater Densities of Some Martian Geologic Units and Features

\begin{tabular}{|c|c|c|c|c|c|c|}
\hline & \multirow[t]{2}{*}{ Unit or Feature } & \multicolumn{5}{|c|}{ Crater Density $\left(\mathrm{N}=\right.$ no. craters $\left.>(X) \mathrm{km} \operatorname{diam} . / 10^{6} \mathrm{~km}^{2}\right)$} \\
\hline & & $N(1)$ & $\mathrm{N}(2)$ & $\mathrm{N}(5)$ & $N(16)$ & $\mathbf{N}(32)$ \\
\hline ' & $\begin{array}{l}\text { Smooth plains material } \\
\text { southern Arcadia } \\
\text { southern Acidalia } \\
\text { Vastitas Borealis Formation } \\
\text { north of lat } 55^{\circ} \mathrm{N} \\
\text { south of lat } 55^{\circ} \mathrm{N} \\
\text { Lava flows, Alba Patera } \\
\text { Noctis Labyriathus } \\
\text { Lava flows, Ceraunius Fossae } \\
\text { Ridged plains material } \\
\text { SW Elysium Planitia } \\
\text { Lava flows, Dorsa Argentea } \\
\text { Ridged plains material } \\
\text { Syrtis Major Planum } \\
\text { Acheron Fossae } \\
\text { Intercrater plains material } \\
\text { Lower Hesperian } \\
\text { Upper Noachian } \\
\text { Cratered terrain material } \\
\text { Impact basins } \\
\text { Argyre } \\
\text { Hellas } \\
\text { Isidis }\end{array}$ & $<50$ & $\begin{array}{l}300-450 \\
150-250 \\
250-375 \\
240-500\end{array}$ & $\begin{array}{c}55 \\
\\
65-85 \\
65-75 \\
55-170 \\
85 \\
100 \\
150 \\
150-170 \\
165 \\
240 \\
160 \\
300-400 \\
300-550\end{array}$ & $\begin{array}{c}30-100 \\
120-240\end{array}$ & $\begin{array}{c}<30 \\
30-100 \\
\\
50 \\
80 \\
130\end{array}$ \\
\hline
\end{tabular}

map unit is extensive and readily identifiable, and because it still provides an excellent boundary for the base of the Hesperian System, I consider it the referent for the Lower Hesperian Series. The type area for the unit remains the same, at lat $20^{\circ} \mathrm{S}$, long $245^{\circ}$ in Hesperia Planum. Here, the ridged plains material forms a smooth surface marked by a pattern of wrinkle ridges similar to those of the lunar maria. The ridges commonly exceed 100 $\mathrm{km}$ in length and $10 \mathrm{~km}$ in width, and they overlap one another. Some wrinkle ridges are found on stratigraphically higher and lower rocks; however, those ridges are generally less common and smaller.

Crater densities of the ridged plains material generally are in a restricted range $[N(5)=125-200]$ that can be used for stratigraphic correlations with other geologic units. The ridged plains material overlies or embays rocks of the Upper Noachian Series in areas south of Chryse Planitia, surrounding Protonilus Mensae, and elsewhere. Wise et al. [1979] postulated that the material is composed of lava flows; Greeley and Spudis [1981] suggested that the flows were of low viscosity and were erupted at high effusion rates.

\section{Upper Hesperian Series}

The Hesperian-Amazonian system boundary was formerly defined by Scott and Carr [1978] as the top of the ridged plains material and the base of the "cratered plains material." The type area for the Amazonian System was defined as lat $18^{\circ}$ $\mathrm{N}$, long $165^{\circ}$ and mapped to include both cratered and smooth plains material [Scott and Carr, 1978]. However, this area has since been found to consist of smooth and ridged plains material [Scott and Tanaka, 1986]. Moreover, areas formerly mapped as cratered plains material have now been shown by recent geologic mapping to consist of many units of the western volcanic assemblage and the Vastitas Borealis, Arcadia, and Elysium Formations [Scott and Tanaka, 1986; Tanaka and Scott, 1987; R. Greeley and J. E. Guest, unpublished data, 1986]. Scott and Tanaka [1986] considered the base of the Amazonian System to be the base of the Arcadia Formation, which includes the smooth plains material within the Amazonis quadrangle.
After formation of the Lower Hesperian ridged plains material and before deposition of the lowermost Amazonian smooth plains material, extensive volcanic, fluvial, and complex plains units were emplaced [Scott and Tanaka, 1986]. Therefore I have selected complex plains material (Vastitas Borealis Formation) to represent the Upper Hesperian Series. This unit is composed of mottled, knobby, and patterned plains materials in Vastitas Borealis (Figure 1), which forms most of the lowland region of Mars north of lat $40^{\circ} \mathrm{N}$. The Vastitas Borealis Formation was formerly mapped as a combination of smooth (Amazonian), cratered (Amazonian), mottled (Noachian), and rolling (Hesperian) plains materials [Scott and Carr, 1978].

Within the formation, densities of craters $>2 \mathrm{~km}$ in diameter tend to be lower north of about lat $55^{\circ} \mathrm{N}$ (Table 3), where smaller craters have probably been erased. At $>5 \mathrm{~km}$ diameter, however, crater densities are uniform and have values consistent with their stratigraphic position.

The members of the Vastitas Borealis Formation are characterized by complex surface features that include the following: (1) a mottled albedo pattern of light crater material superposed on dark intercrater material, (2) small knobs of varied density, (3) troughs that form polygons 5 to $20 \mathrm{~km}$ in diameter, and (4) ridges that form both polygonal and concentric patterns. The composition of the materials is unknown but may include lava flows, sediments, and pyroclastic materials [Greeley and Spudis, 1981; McGill, 1985]. Origins of the knobs, ridges, and grooves have attributed to mass wasting, periglacial deformation, volcanism, and tectonism [Carr and Schaber, 1977; Scott, 1979, Pechmann, 1980].

\section{Lower Amazonian Series}

As discussed above, I redefined the base of the Amazonian System because of complexities newly discovered by geologic mapping of units at the base of the system. The new referent is the smooth plains material that makes up the lowermost member of the Arcadia Formation [Scott and Tanaka, 1986], which is exposed principally in southern Amazonis and southerm Acidalia Planitiae. This rock unit is moderately cratered and 
smooth, and it surrounds small knobs and high areas of older materials. The type area of the smooth plains material is at lat $33^{\circ} \mathrm{N}$, long $30^{\circ}$. The unit overlies ridged plains material in southern Amazonis Planitia; the Vastitas Borealis Formation in Acidalia Planitia; northern, lower flows of Alba Patera; and Upper Hesperian flood-plain deposits. Lobate flow scarps and distributary channels in this lowermost member of the Arcadia Formation in Amazonis Planitia indicate that it is made up partly of lava flows and fluvial deposits; it may also include eolian material. Densities of craters larger than $2 \mathrm{~km}$ in diameter for the unit differ from place to place, indicating differences in relative ages and perhaps in crater degradation.

\section{Middle Amazonian Series}

Smooth plains material in Amazonis Planitia, which characterizes the Amazonian System [Scott and Carr, 1978], was shown to be composed of five overlapping members of the Arcadia Formation [Scott and Tanaka, 1986]. Members 2 and 3 , which are lava flows, are similar in stratigraphic position to some of the extensive volcanic rocks of the Tharsis Montes Formation and to thick, degraded materials that compose the lower and middle members of the Medusae Fossae Formation. A Middle Amazonian Series is proposed to distinguish the position of these two members of the Arcadia Formation. Their type area is at lat $30^{\circ} \mathrm{N}$, long $160^{\circ}$. Here, member 3 is smooth, sparsely cratered, and marked by a few scarps that appear to be the edges of lava flows. It overlies the lowermost member of the Arcadia Formation in Amazonis Planitia and embays the Olympus Mons aureoles, and it is overlain by upper members of the Arcadia in southern Arcadia Planitia and apparently by the upper member of the Medusae Fossae Formation in southern Amazonis Planitia. Densities of craters $>2 \mathrm{~km}$ in diameter are useful in correlating rock units of Middle Amazonian age.

\section{Upper Amazonian Series}

New mapping of Mars has revealed many young units that have few superposed kilometer-size craters. These include uppermost members of the Arcadia, Olympus Mons, Medusae Fossae, and Tharsis Montes Formations and polar, eolian, landslide, debris-apron, and channel materials [Scott and Tanaka, 1986; Tanaka and Scott, 1987]. Upper Amazonian materials are noteworthy because of their relative youth and their consequent indication of current and potential Martian geologic activity. Recent mapping in southern Elysium Planitia [Tanaka and Scott, 1986; R. Greeley and J. E. Guest, unpublished data, 1986] has delineated vast, smooth flood-plain material that appears to have been deposited by floods emanating from western Cerberus Rupes. This unit is chosen as the referent for the Upper Amazonian Series; the type area is at lat $6^{\circ} \mathrm{N}$, long $208^{\circ}$. The area of the flood plain exceeds $100,000 \mathrm{~km}^{2}$ and it extends from long $168^{\circ}$ to $222^{\circ}$ (nearly $3000 \mathrm{~km}$ ); it is more than $750 \mathrm{~km}$ wide at long $195^{\circ}$. The unit consists of low-albedo material marked by light, wispy streaks. Channel scarps and teardrop-shaped bars are observed near the source and south and east of Orcus Patera. The east channel of the flood plain cuts into materials that include the Medusae Fossae and Arcadia Formations. Cited crater densities of the channel floors are $\mathrm{N}(1)<600$ [Carr and Clow, 1981] and $\mathrm{N}(1)<50$ [Scott and Tanaka, 1982]. Sparse cratering of the entire regional flood plain supports the smaller crater count. Most craters larger than about $1 \mathrm{~km}$ in diameter appear embayed by the flood-plain material, indicating that the deposits are perhaps only tens of meters thick.

\section{CRATER-DENSITY BOUNDARIES FOR MARTIAN SERIES}

Relative-age limits defined by crater densities for the Martian series were derived from crater counts of referents and from other units of like statigraphic position. Table 3 summarizes crater densities determined in this study.

Increasing diameters are used for crater-density ranges of series of increasing age for several reasons. First, images of most areas generally allow identification of craters no smaller than 1-2 km in diameter. Second, a large proportion of craters several kilometers in diameter or less are obliterated on older surfaces. Third, the density of large craters is generally too sparse on younger surfaces for determining precise crater densities. Another effect that is not yet well studied is difference in crater size caused by different target-material properties [Boyce and Witbeck, 1985].

Generally, densities of craters larger than $16 \mathrm{~km}$ in diameter were determined for the Noachian referents. This diameter was used in counts for several terrain types [Gurnis, 1981], and for recently mapped units on Mars [Scott and Tanaka, 1986]. At this diameter and greater, the effect of crater obliteration is negligible [Woronow, 1977]. On Upper Noachian intercrater plains material and some older resistant terrains, however, craters as small as $5 \mathrm{~km}$ in diameter are sufficiently well preserved to yield reliable relative ages from crater counts.

For moderately resurfaced Hesperian and Lower Amazonian surfaces, 5-km-crater densities (N(5)) were mostly used in order to avoid obliteration effects and to maintain a sufficient sample size. On many Tharsis region and northern plains units, crater densities were determined at this 5-km size [e.g., Scott and Tanaka, 1981b; Plescia and Saunders, 1982; Dial, 1984; Witbeck and Underwood, 1984; Table 3]. However, authors of many published crater counts cite densities for Hesperian to Amazonian units at other sizes as well [e.g., N(4-10), Condit, 1978; N(1), Neukum and Hiller, 1981].

For Middle and Upper Amazonian surface, the 2-km-crater densities (N(2)) are optimal for general application. Frequencies of smaller craters of similarly aged surfaces range widely due to secondary craters, nonimpact craters, and resurfacing [Soderblom et al., 1974; Neukum and Wise, 1976; Hartmann et al., 1981]. For the youngest surfaces, however, the statistical sample of craters $2 \mathrm{~km}$ in diameter is small, and crater-density data have little value.

Crater size-frequency distributions of Amazonian and Hesperian Tharsis plains units follow approximately a -2 power law for cumulative numbers of craters larger than $1 \mathrm{~km}$ [Hartmann, 1977; Tanaka, 1985c]. On the basis of this power law, densities of $N(1)$ and $N(4-10)$ craters were converted to $N(2)$ and $N(5)$ counts. Thus crater-density ranges that were determined for Hesperian and Amazonian series at 2- and 5$\mathrm{km}$ diameters were converted to $\mathrm{N}(1)$ and $\mathrm{N}(4-10)$ densities for easy cross-reference (Table 2). The $N(1)$ values should be used cautiously because of their variation, as described above.

In most cases, crater densities for the referents span the range given in Table 2. However, small areas of some units have crater frequencies that suggest overlap into adjacent series.

\section{ABsolute Ages of MARTIAN Epochs}

Several models have been made to determine absolute ages of surfaces on Mars; they remain a subject of controversy. The 


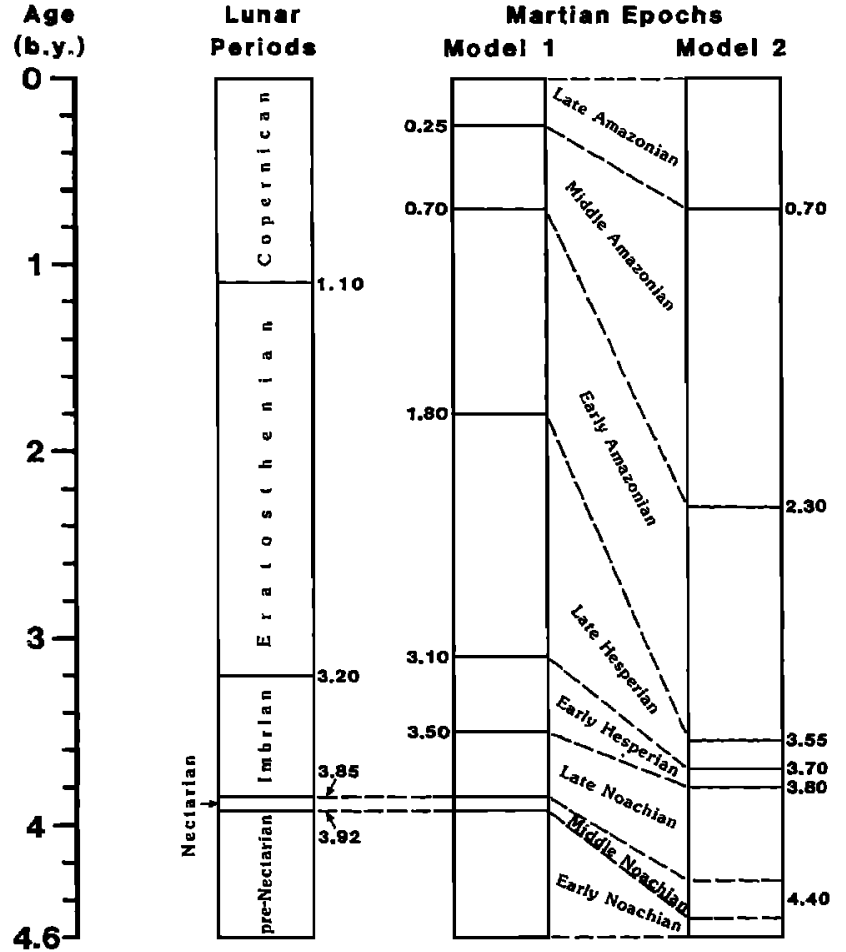

Fig 2. Chart showing model chronologies for the moon and Mars. Absolute ages for lunar periods from Wilhelms [1980, 1986]. Inferred ages for Martian Hesperian and Amazonian epochs are based on craterdensities of series (Table 2) and correlation to model chronologies of Neukum and Wise [1976] (Model 1) and Hartmann et al. [1981] (Model 2). Because of obliteration of smaller Noachian craters, these models could not be used directly for the Noachian boundaries. Neukum and Wise [1976] assigned a 4.4 b.y. age to cratered terrain material (Middle Noachian rocks) but gave no age range; thus the boundaries of this epoch are dashed. Noachian ages derived in this paper are compatible with the Hartmann model and are combined with the Hesperian and Amazonian ages of that model.

models allow prediction of the relation between crater density and absolute age of Martian surfaces based on (1) the same relation derived for lunar rocks from sample data, and (2) the ratio of the cratering fluxes of Mars and the moon. Because these factors are not precisely determined, estimates of craterproduction rates for Mars differ considerably. The results of two dominant crater-chronology methods, one by Neukum and Wise [1976] and another by Hartmann et al. [1981], demonstrate the range in estimates. They are given in Figure 2, and the methods and assumptions are briefly reviewed here [see also the review by Carr, 1981, p. 61].

Neukum and Wise [1976] first developed a correlation between $N(1)$ and radiometric ages for lunar sites based on a review of existing models. They then determined a "production sizefrequency distribution" (or calibration curve) for lunar craters between 0.3 and $20 \mathrm{~km}$ in diameter in the age range of $3 \mathrm{~b} . \mathrm{y}$. to older than 4 b.y. [Neukum et al., 1975] and compared it to a similar distribution derived for Mars based on Mariner 9 images. The Mars distribution was found to be somewhat flatter. Neukum and Wise [1976] suggested that this difference was caused by the production of craters having diameters 1.5 times larger on the moon than on Mars because of the greater average impact velocity of meteoroids bombarding the lunar surface. They assigned a frequency of $1-\mathrm{km}$-diameter craters to lunar highlands that have an age of $4.4 \mathrm{~b}$.y. by projection from the $100-\mathrm{km}$-diameter crater population, using their calibration curve. Similarly, heavily cratered terrain on Mars was assigned a 1-km-crater density on the basis of frequencies of larger craters in Tempe Terra (quadrangle MC-3). Assuming that the highlands terrains are all of about the same age and accounting for velocity effects, Neukum and Wise deduced that the crater-production rate on Mars is 4.5 times lower than on the moon. They also indicated that Phobos is about 4.5 to 4.6 b.y. old, and that a comparison of crater densities between Phobos and the Martian highlands suggests a 4.4 b.y. age for the highlands. Considering crater-scaling effects, they suggested that the meteoroid flux at Mars and the moon was the same within a factor of 2 . On the other hand, reviewing the craterproduction rates on Mars determined by various authors and considering the astronomical effects of known asteroid and comet populations, impact velocities, gravity, and energy scaling, Hartmann et al. [1981, p. 1080] suggested a Martian crater flux twice that of the moon to be the most likely, and a range between a factor of 1 and 4 to be possible.

The difference of a factor of 2 in relative crater-production rates between the Neukum and Hartmann proposals creates quite different chronologies for the Martian epochs. A major uncertainty in the Neukum and Wise model is the age of the Martian highlands. Can this be ascertained by using only the assumption that the meteoroid populations have the same sizefrequency distribution for both planets? (This assumption is common to both chronology models.) An attempt is made in the following discussion.

The distribution of craters larger than $10 \mathrm{~km}$ in diameter on Noachian surfaces deviates from a simple power-law function and is more precisely expressed by a lognormal distribution [Woronow, 1977]. Specifically, fewer smaller craters are found than expected for a power-law distribution. The lognormal distribution also describes the population of ancient craters on the moon [Wilhelms et al., 1978]. On Mars, this distribution may either (1) reflect the actual ancient distribution of impact craters that, in turn, may represent a population of planetesimals that bombarded the planet [Strom and Whitaker, 1976; Gurnis, 1981] or (2) result from intense obliteration of smaller craters that were originally part of a power-law distribution [Hartmann, 1973; Chapman and Jones, 1977]. Woronow [1977] indicated from several lines of evidence and theory that a simple powerlaw function does not explain the large-crater distribution on Mars, and that crater obliteration was mainly confined to craters $<15 \mathrm{~km}$ in diameter. Therefore $I$ assume that the Martian population of craters larger than $15 \mathrm{~km}$ in diameter closely reflects the initial distribution for the Middle Noachian Epoch, and that craters having smaller diameters are more fully preserved on surfaces of higher stratigraphic positions.

Highland surfaces on the moon and on Mars have similar large-crater distributions [Strom, 1979, Figure 20]. More specifically, the distribution of lunar Nectarian craters [Wilhelms et $a L, 1978]$ is statistically similar to that of Martian craters (scaled in size on the basis of relative gravity and velocity effects) on Middle Noachian highland surfaces [Tanaka, 1984]. In order to compare more accurately lunar and Martian crater distributions, I modified the Martian distributions of craters larger than $16 \mathrm{~km}$ in diameter so that only the crater distributions of particular epochs are represented, such as in the lunar counts by Wilhelms et al. [1978]. Furthermore, I increased the diameters of Martian craters by a factor of 1.3 to account for gravityand velocity-scaling effects [Tanaka, 1984]. The lunar distributions are statistically distinct from each other according to a $\chi^{2}$ test of binned crater-size frequencies with a $99 \%$ 


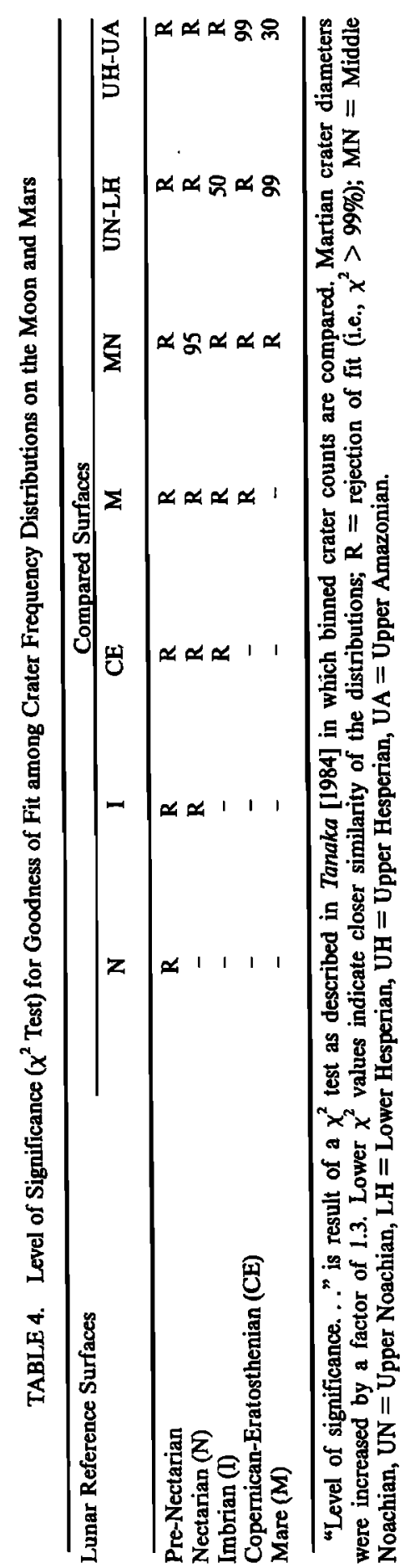

acceptance cutoff (Table 4). I used counts by Gurnis [1981] to represent the crater distributions of time-stratigraphic units on Mars, and I subtracted the frequency of craters superposed on intercrater plains material (Upper Noachian) from their frequency on cratered terrain material (Middle Noachian), leaving a remainder of Middle Noachian craters. I did the same for intercrater plains material and the Vastitas Borealis Formation (Upper Hesperian) to derive a crater distribution for the interval between the Late Noachian and the Early Hesperian. Binned counts for craters of Middle Noachian age $>16 \mathrm{~km}$ in diameter correlate with the lunar Nectarian crater distribution (Table 4). For craters $>8 \mathrm{~km}$ in diameter, the Late Noachian to Early Hesperian distribution correlates well with that for the lunar Imbrian System [Wilhelms et al., 1978] but only fairly well with the lunar mare distribution [Hartmann, 1978], and the Late Hesperian to Amazonian distribution matches the average lunar mare and Copernican-Eratosthenian distributions [Wilhelms et al., 1978].

The similarity in crater distributions of the Middle Noachian Series and the Nectarian System suggests that they may have about the same average age. This suggestion can be accommodated by the Hartmann model, which indicates an age range of 3.8-4.2 b.y. (4.0 most likely) for the heavily cratered terrain, but not be the Neukum model, which requires that the age of the Martian cratered terrain (Middle Noachian) be abaut 4.4 b.y. The crater-density ratio between Martian Middle Noachian and lunar Nectarian surfaces is about 2.0, which suggests that the periods are similar in duration, based on a crater-production ratio of 2.0 . Within these guidelines, I haye set the limits of the Middle Noachian Epoch at 3.92 and 3.85 b.y.--the same as the lunar Nectarian Period (Figure 2)

The Lower Noachian Series, then, is older than 3.92 b.y. The base of the Lower Hesperian Series, according to the craterdensity boundary (Table 2) and the Hartmann chronology, is 3.5 b.y. old. The Late Noachian Epoch thus is assigned the period from 3.85 to $3.5 \mathrm{~b}$.y. The crater distribution and inferred age (3.85-3.10 b.y.) of the interval between the Late Noachian and Early Hesperian Epochs on Mars nearly corresponds to. that of the Imbrian Period on the moon [3.85-3.20 b.y.; Table 4; Wilhelms, 1980, 1986]. Cumulative crater distributions for surfaces younger than about 3.5 b.y. on both the moon and. Mars generally follow a -2 power law. These surfaces include those of lunar Eratosthenian and Copernican rocks [ $<3.2$ b.y.; Wilhelms et al., 1978, Figure 6; Wilhelms, 1980, 1986]; lunar mare (3.8 to 1.0 b.y.; D. E. Wilhelms, personal communication, 1986); and Martian post-Noachian (<3.5 b.y.) rocks. The Upper Hesperian to Upper Amazonian crater distribution on Mars correlates with the distributions of these younger lunar rocks (Table 4).

\section{STRATIGRAPHIC-AGE DETERMINATIONS OF GEOLOGIC UNITS' AND FEATURES}

The referents (Table 1) and crater-density boundaries (Table 2) for the series defined above form the basis for stratigraphicage determinations of geologic units and features on Mars. Many. crater counts for such units and features are already published; additional counts performed in order to complete this study are given in Table 3. (More complete documentation of many of these new counts is intended for future publication.)

Crater counts are generally published in graph or tabular form, and crater densities can be read directly or adjusted to one or more of the size ranges shown in Table 2. Exceptions: 
are the data in Hartmann et al. [1981, Table 8.6.1], which are ratios of crater densities (mostly at $4 \mathrm{~km}$ diameter) relative to a typical lunar-mare crater distribution [in which $\mathrm{N}(4)=188$ ]. Assuming that the counts follow a -2 power-law distribution (which is approximate), I converted the ratios to $N(5)$ by multiplying them by a factor of 125 and to $N(2)$ by using a factor of 750 .

Martian geologic units and features in this study (Table 5) are classified as follows:

(1) Plains and highland units. Deposits that have miscellaneous (e.g.. volcanic, eolian, mass-wasting, impact) or uncertain origins.

(2) Volcanoes and associated lavaflows. Features that have definitive volcanic morphologies.

(3) Channels. Includes outflow, fretted, and runoff types.

(4) Fracture systems. Most are related to Tharsis tectonism.

(5) Impact basins. Circular, multiringed structures larger than $200 \mathrm{~km}$ in diameter.

Generally, crater-density ages and stratigraphic relations closely complement each other. Where crater densities determined by various authors are assigned to series, the relative ages of most features are in fair agreement. Where discrepancies exist, stratigraphic relations are used to determine the relative age as precisely as possible. However, some of the features are volcanic provinces or volcano groups that have had long periods of activity; the inferred entire durations are given in Table 5. The relative ages of channels, fractures, and impact basins were mostly determined by overlap relations or crater counts of the surfaces that they cut or overlie; only a few of the ages refer to the features themselves.

\section{StratigraPhIC MAPS OF MARS}

To summarize the vast amount of stratigraphic data in a simple, consistent, and legible format, the time-stratigraphic series described above are portrayed in map form. Formal geologic mapping of Mars at 1:15,000,000 scale from Viking images is nearly complete [Scott and Tanaka, 1986; Tanaka and Scott, 1987; R. Greeley and J. E. Guest, unpublished data, 1986] and was heavily relied on to complete a stratigraphic map of the entire surface of the planet. The spatial and temporal resolution of the stratigraphic mapping surpasses previous work. The resulting maps are shown on Plate la-c.

A few exposures consist of materials that were emplaced over long time spans, such as canyon-wall material in Valles Marineris, etched terrain near the south pole, and knobby plateau remnants in the northern plains. These materials are mostly Lower to Upper Noachian, but for simplicity all are shown as Middle Noachian on the maps. Likewise, the activities of many volcanoes and fracture sets cover wide age ranges, but only the latest or average surface ages are presented on the maps. Detailed age ranges, stratigraphic relations, and crater-count sources of these units and features are compiled in Table 5. Overall, the maps provide an easy reference for the stratigraphic positions of all major units on Mars.

\section{GEOLOGIC HISTORY OF MARS}

In the following sections, the surface history of Mars is reviewed, adding a geologic perspective to the stratigraphic maps on Plate 1. The individual epochs are characterized by events and activities that are governed by planetesimal bombardment, the deep mantle and lithosphere (manifested by volcanotectonic regions), surface properties, and atmospheric effects. Collectively, they help to unravel the evolution of the planet.

\section{Early Noachian Epoch}

The oldest exposed materials on Mars are: (1) basin-rim material surrounding Isidis, Hellas, Argyre, south polar, and other basins, and (2) isolated hilly or mountainous material. These materials characteristically have bold relief and are embayed by cratered plains material. The bold relief indicates that the Martian lithosphere was sufficiently thick, cool, and elastic during this early period to preserve large crater forms. Crater densities are generally in the range $N(16)=120$ to 300 ; however, because of substantial degradation and fill within low areas, the crater-density data commonly are not representative of the age of the material. From superposition relations with cratered terrain material, the Lower Noachian series is assigned $\mathbf{N}(16)>200$. If the crater populations have been degraded in a consistent fashion, crater counts (Table 3 ) indicate that the oldest of the three largest basins is Isidis, followed by Hellas and then Argyre. This sequence is also supported by comparisons among the basins of the relief and degree of preservation of mountain-ring structures. Erosion probably was not the main cause of the lower relief of the older basin rims, as suggested by the moderate amount of obliteration of superposed craters. More likely, the greater diameter of the older basins and probable higher crustal temperatures caused greater viscous relaxation of their rims. Most other Martian impact basins identified or postulated [Schultz et al., 1982] appear older than or equivalent in age to the Middle Noachian cratered plains, and their positions are designated as Lower to Middle Noachian (Table 5). Other isolated hilly material is exposed in relatively small patches surrounding the Tharsis region and in patches in the eastern part of Mars; they may also be old basin-rim remnants of old volcanic or tectonic mountains [Scott and King, 1984].

Knobby remnants of heavily cratered terrain occur in the northern plains as far north as Scandia Colles (Figure 1) and other localities north of the highland-lowland boundary scarp. Their occurrence suggests that the northern, topographically low region (several kilometers below the highland surface) was formed during the Early Noachian Epoch. This low region is approximately circular and has a diameter of about $130^{\circ}$ of latitude. Faults radial and concentric to the Argyre, Hellas, and Isidis impact basins formed during the Early Noachian and on into the Middle Noachian, according to crater counts [Wichman and Schultz, 1986] and transection relations with plateau rocks.

\section{Middle Noachian Epoch}

The Middle Noachian Epoch represents the final period of heavy bombardment on Mars, when cratering rates were very high and crater-production distribution may have been lognormal [Woronow, 1977]. Consequently, many of the smaller impact basins are of this age (Table 5). Crater counts of the Middle Noachian Series referent, the cratered terrain material, were obtained from the following Mars Charts: 3, 10 [Neukum and Wise, 1976]; 20, 22, 23, 26 [Gurnis, 1981]; 20, 23 (A. L. Dial, Jr., personal communication, 1984); and 10,11, 18, 19 , 24, 25, 26 [Tanaka, 1985a]. Crater densities mostly fall in the range of $N(16)=120$ to 240 , concentrated within the range of $N(16)=160$ to 200 . Resurfacing and erosional effects were minimized for the counts in this study by avoiding intercrater deposits (mapped as younger units) and dissected, knobby, and etched exposures [Scott and Tanaka, 1984]. Even so, in some 


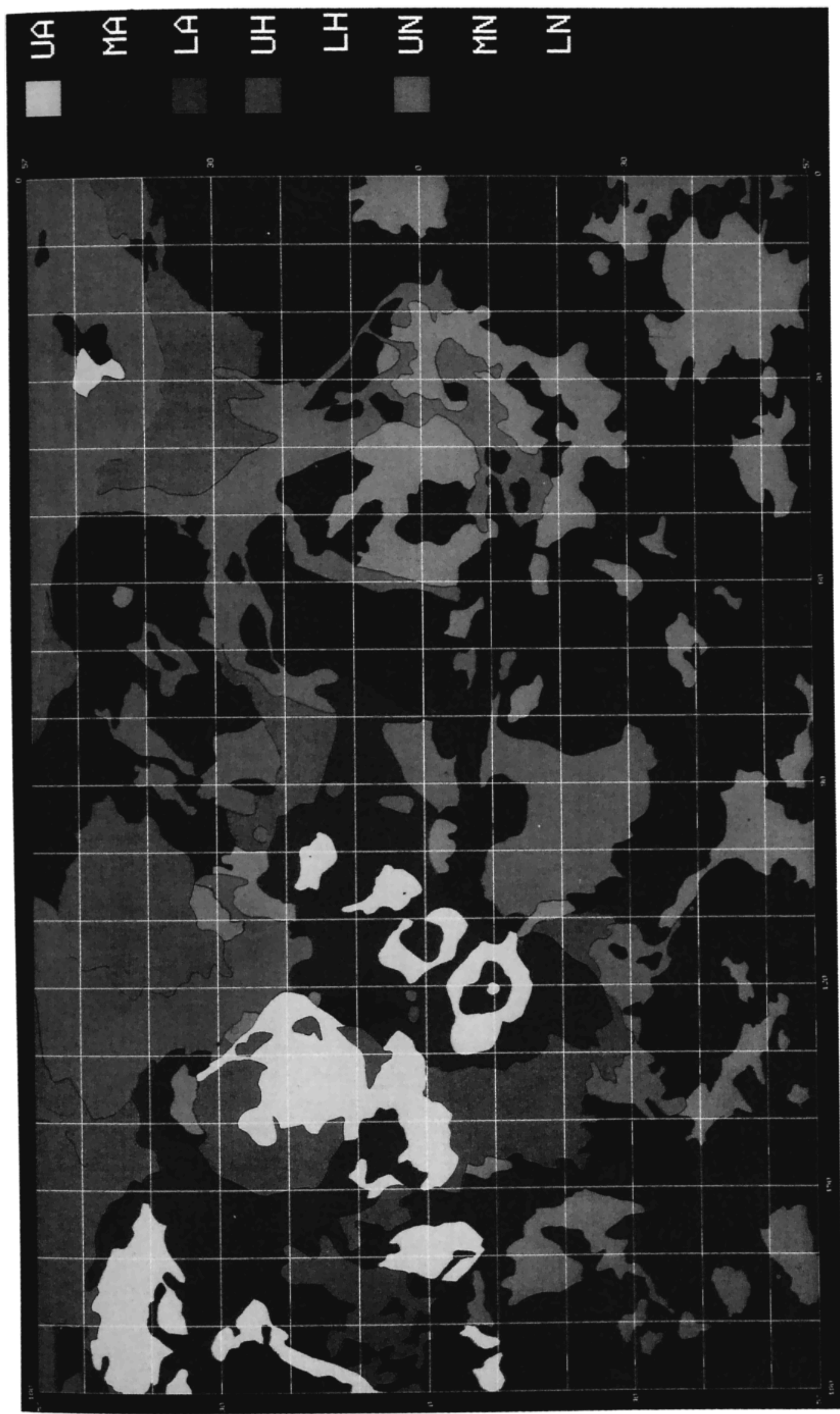

边起

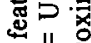

范高

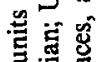

음

응

远定

踏

言富

政

品过造

a

ड.

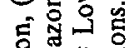

응 11 .

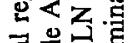

.

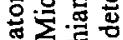

宗 II

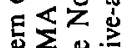

口

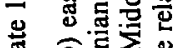

要 可

5

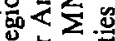

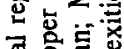

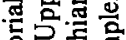

임 要远

E

造

\&.

可高志

응

$\sum$ 驾. .

ㄴㅇㅎ항

品论

更

㐘产喜

릉

롱리 $1 \mid$

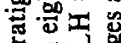

究.

丞

的总

究虰通 


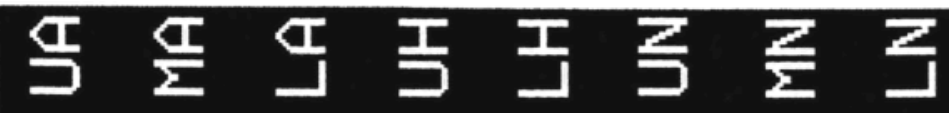

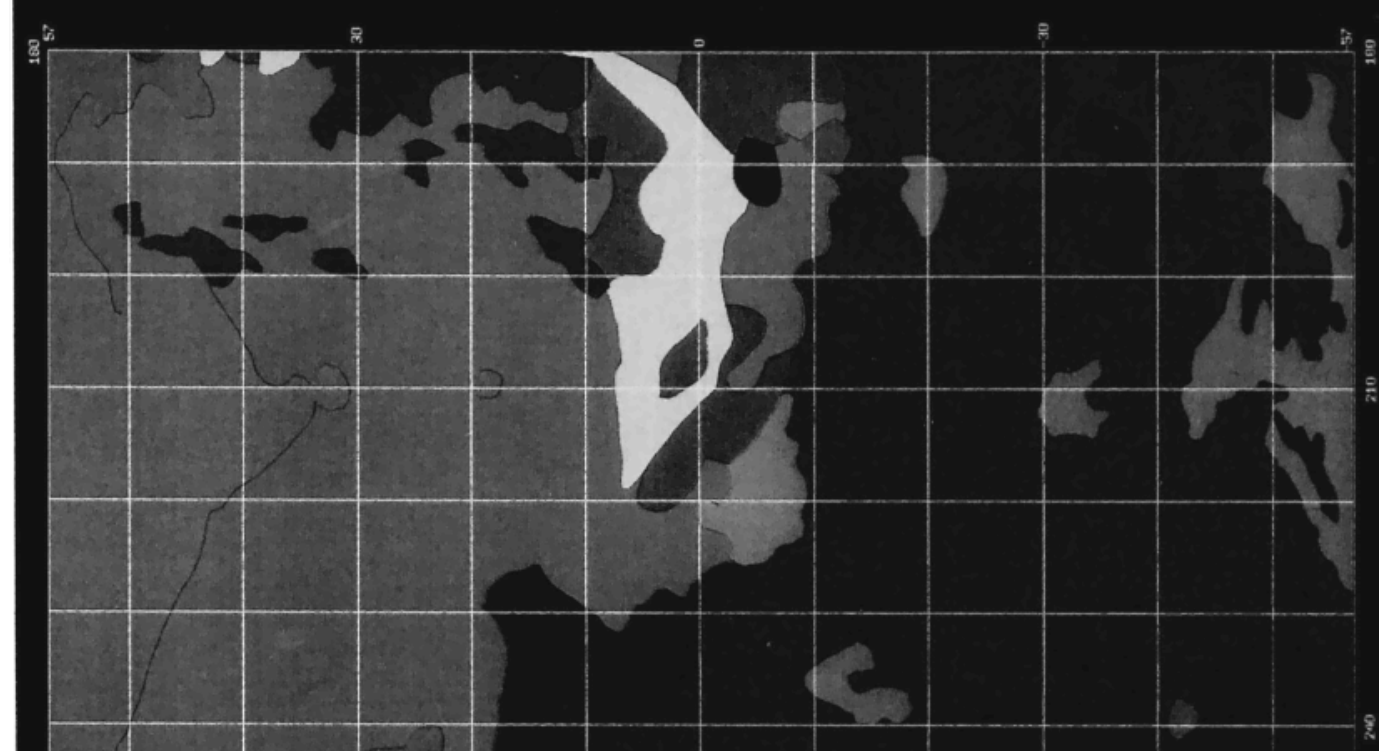




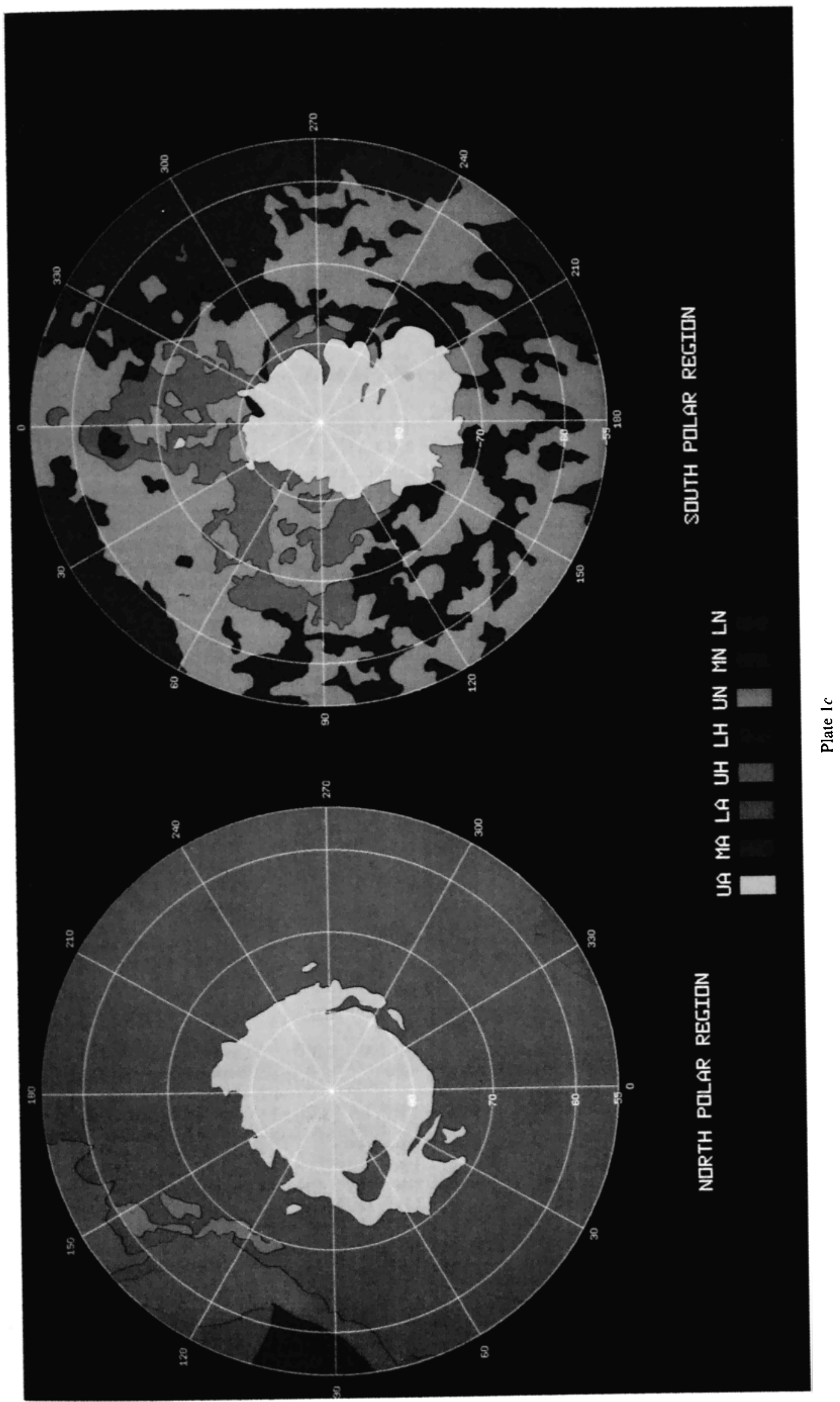


TABLE 5. Stratigraphy of Martian Geologic Units and Features

\begin{tabular}{|c|c|c|c|}
\hline Unit or Feature & $\begin{array}{l}\text { Stratigraphic } \\
\text { Position }\end{array}$ & Cited Crater Ages & Key Geologic Relations \\
\hline $\begin{array}{l}\text { Polar dunes, mantle, ice, and } \\
\text { layered deposits }\end{array}$ & $\begin{array}{l}\text { A. Plains and } \\
\text { UA (and lower?) }\end{array}$ & $\begin{array}{l}\text { Highland Units } \\
\mathrm{MA}^{(1)}, \mathrm{UA}^{(2)}\end{array}$ & \\
\hline \multicolumn{4}{|l|}{ Landslides } \\
\hline Olympus Mons & UA & none & $=$ Olympus flows (UA) \\
\hline Valles Marineris & MA-UA & $\mathbf{M A}^{(3)}$ & $<$ layered deposits (UH) \\
\hline \multicolumn{4}{|l|}{ Debris aprons } \\
\hline $\begin{array}{l}\text { Tharsis Montes } \\
\text { mensae terrain }\end{array}$ & $\begin{array}{l}\text { UA } \\
\text { MA-UA }\end{array}$ & $\begin{array}{l}\text { none } \\
\mathrm{MA}^{(4)}, \mathrm{MA}^{(5)}\end{array}$ & $\begin{array}{l}=\text { Tharsis flows (UA) } \\
<\text { <mooth plains (LA) }\end{array}$ \\
\hline $\begin{array}{l}\text { Thick deposits, southern } \\
\text { Amazonis Planitia }\end{array}$ & MA-UA & MA-UA $^{(6)}$ & $\begin{array}{l}\text { <smooth plains (LA-MA); } \\
\leq \text { Olympus Mons aureoles } \\
\text { and Tharsis flows (MA) }\end{array}$ \\
\hline \multicolumn{4}{|l|}{ Smooth plains } \\
\hline $\begin{array}{l}\text { Malea Planum } \\
\text { northern }\end{array}$ & $\begin{array}{l}\text { UH-LA (or higher) } \\
\text { LA to UA }\end{array}$ & $\begin{array}{l}\text { none } \\
\text { MA }^{(7)}, \text { LA-UA }\end{array}$ & $\begin{array}{l}\text { <ridged plains (LH) } \\
\text { <Vastitas Borealis (UH), } \\
\text { Elysium flows (UH-LA), } \\
\text { Chryse flood plains (UH) }\end{array}$ \\
\hline Vastitas Borealis & UH & $\begin{array}{l}U^{(2)}, \mathbf{U H}^{(8)}, \mathrm{LA}^{(9)} \\
\text { LH-LA }{ }^{(10)}, \mathrm{UH}^{(11)}\end{array}$ & $\begin{array}{l}\text { <ridged plains (LH); } \\
\text { Elysium flows (UH); } \\
\text { >smooth plains (LA) }\end{array}$ \\
\hline $\begin{array}{l}\text { Layered deposits, Valles } \\
\text { Marineris }\end{array}$ & UH & none & $\begin{array}{l}<\text { Valles Marineris }(\mathrm{LH}) \\
\text { outflow channels }(\mathrm{UH})\end{array}$ \\
\hline Argyre and Hellas Planitiae & UN-UH & $U N^{(1)}, U^{(10)}$ & $\begin{array}{l}\text { Sridged plains (LH), Dorsa } \\
\text { Argentea plains (LH) }\end{array}$ \\
\hline Ridged plains material & LH & $\begin{array}{l}\text { UN-LH }{ }^{(1)}, L_{H}^{(8)} \\
\mathbf{U H}^{(9)}, \mathbf{L H}^{(10)}, \mathbf{L} \dot{H}- \\
\mathbf{U H}^{(12)}, \mathrm{UH}^{(13)}, \\
\mathbf{L H}^{(14)}\end{array}$ & $\begin{array}{l}\text { Sintercrater plains (UH-LH); } \\
\text { >Syria Planum flows (UH), } \\
\text { Vastitas Borealis (UH) }\end{array}$ \\
\hline Intercrater plains material & UN-LH & $\begin{array}{l}\mathrm{UN}-\mathrm{LH}^{(8)}, \mathrm{UN}^{(14)} \\
\mathrm{UN}-\mathrm{LH}^{(15)}\end{array}$ & 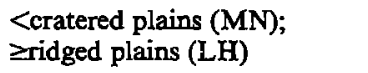 \\
\hline & MN & $\mathrm{MN}^{(8)}, \mathrm{MN}^{(15)}$ & $\begin{array}{l}\text { <basement material (LN); } \\
\text { >intercrater plains (UN) }\end{array}$ \\
\hline $\begin{array}{l}\text { craters smaller than } 10 \mathrm{~km} \text { in } \\
\text { diameter }\end{array}$ & UN-LH & $\begin{array}{l}\mathrm{LH}^{(1)}, \mathrm{UH}^{(4)}, \mathrm{UN}- \\
\mathrm{LH}^{(8)}, \mathrm{UH}^{(9)} \\
\mathrm{LH}^{(12)}, \mathrm{UN}^{(16)}\end{array}$ & $\begin{array}{l}\text { Scratered plains dissection } \\
(\mathrm{UN})\end{array}$ \\
\hline Basement material & LN & $\mathrm{LN}^{(17)}$ & >cratered plains (MN) \\
\hline $\begin{array}{l}\text { Olympus Mons (including } \\
\text { aureoles) }\end{array}$ & $\begin{array}{l}\text { B. Volcanoes and } A \\
\text { LA(or lower)-UA }\end{array}$ & $\begin{array}{l}\text { Issociated Lava Flows } \\
\mathrm{MA}^{(1)}, \mathrm{UH}-\mathrm{UA} \mathrm{A}^{(7)} \\
\mathrm{UA}^{(9)}, \mathrm{UA}^{(12)} \\
\mathrm{UA}^{(13)}\end{array}$ & $\begin{array}{l}\text { <Ulysses Fossae (LH), } \\
=\text { Tharsis flows (MA-UA); } \\
\text { 2thick Amazonis deposits } \\
\text { (MA-UA); > Tharsis flows } \\
\text { (MA) }\end{array}$ \\
\hline \multirow{2}{*}{$\begin{array}{l}\text { Ceraunius Fossae flows } \\
\text { Tharsis Montes (including } \\
\text { flows) }\end{array}$} & UH-LA & $\mathrm{UH}^{(8)}, \mathrm{LA}^{(17)}$ & $\leq$ Alba Patera flows (LH-LA) \\
\hline & UH(or lower)-UA & $\begin{array}{l}\text { UH-MA }{ }^{(1)}, \text { LA- } \\
\text { MA }^{(9)}, \text { LA-UA }^{(12)} \\
\text { LA-UA }^{(13)}, \mathbf{U H}- \\
\text { UA }^{(14)}, \text { LA }^{(18)}\end{array}$ & <ridged plains $(\mathrm{LH})$ \\
\hline Small Tharsis volcanoes & UH-LA & UH-LA ${ }^{(13)}, \mathbf{L H}^{(18)}$ & $>$ Tharsis flows (UH-MA) \\
\hline $\begin{array}{l}\text { Small volcanoes(?) in northern } \\
\text { plains }\end{array}$ & UH-LA (or higher) & none & $\leq$ Vastitas Borealis (UH) \\
\hline Elysium volcanoes & UH-LA & 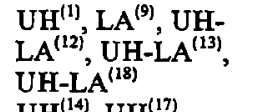 & $\begin{array}{l}\text { <ridged plains (LH); } \\
\leq \text { Vastitas Borealis (UH); } \\
\text { >smooth plains (LA-MA) }\end{array}$ \\
\hline Syria Planum flows & UH & $\mathrm{UH}^{(14)}, \mathrm{UH}^{(17)}$ & <ridged p lains (LH) \\
\hline Alba Patera flows & LH-LA & $\begin{array}{l}\mathrm{UN}^{(1)}, \mathbf{U H}^{(4)}, \mathrm{UN}- \\
\mathrm{LH}^{(7)}, \mathbf{L A}^{(9)}, \mathbf{L A}^{(12)} \\
\mathrm{UH}^{(13)}, \mathrm{LH}^{(17)}, \\
\mathrm{LH}^{(18)}\end{array}$ & $<$ Ceraunius Fossae (UN) \\
\hline Tempe Fossae flows & LH-UH & none & $\begin{array}{l}\text { <ridged plains (LH); =lower } \\
\text { Alba Patera flows (LH-UH) }\end{array}$ \\
\hline Dorsa Argentea flows & LH to UH & $L^{(8)}$ & $<$ ridged plains (LH) \\
\hline Syrtis Major flows & LH & $\mathrm{UN}^{(1)}, \mathrm{LH}^{(8)}$ & $\begin{array}{l}\text { Cintercrater plains (UN); } \\
\text { >Vastitas Borealis plains } \\
\text { (UH) }\end{array}$ \\
\hline Highland paterae & UN to $\mathrm{LH}$ & $\begin{array}{l}\mathbf{L H}^{(1)} \mathbf{U N}^{(13)} \\
\mathrm{UH}^{(13)}\end{array}$ & Zridged plains (LH) \\
\hline Highland volcanoes & $\mathrm{MN}$ to $\mathrm{UN}$ & none & $\begin{array}{l}\text { Scratered plains }(\mathrm{MN}) \\
\text { >ridged plains }(\mathrm{LH})\end{array}$ \\
\hline
\end{tabular}


TABLE 5. (continued)

\begin{tabular}{|c|c|c|c|}
\hline Unit or Feature & $\begin{array}{l}\text { Stratigraphic } \\
\text { Position }\end{array}$ & Cited Crater Ages & Key Geologic Relations \\
\hline \multicolumn{4}{|r|}{ 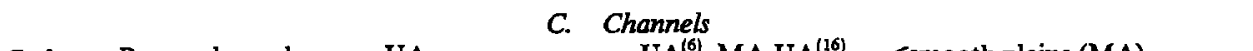 } \\
\hline $\begin{array}{l}\text { Cerberus Rupes channel } \\
\text { Hrad, Tinjar, and Granicus } \\
\text { Valles }\end{array}$ & $\begin{array}{l}\text { UA } \\
\text { LA }\end{array}$ & $\begin{array}{l}\mathrm{UA}^{(6)}, \mathrm{MA}-\mathrm{UA} \mathrm{A}^{(16)} \\
\text { none }\end{array}$ & $\begin{array}{l}\text { <smooth plains (MA) } \\
\text { <Vastitas Borealis (UH); } \\
\text { =Elysium flows (LA) }\end{array}$ \\
\hline $\begin{array}{l}\text { Outflow channels, flood plains } \\
\text { and chaotic terrain }\end{array}$ & UH & $\begin{array}{l}\mathrm{UH}^{(1)}, \mathrm{UH}-\mathrm{UA}^{(4)} \\
\mathrm{LA}^{(9)}, \mathrm{UH}^{(16)}, \mathrm{LH}- \\
\mathrm{MA}^{(18)}\end{array}$ & $\begin{array}{l}\text { <ridged plains (LH); } \\
\text { >smooth plains (LA) }\end{array}$ \\
\hline Mangala Valles & UH-LA & $\begin{array}{l}\text { LA }^{(16)}, \text { LH-UH }^{(17)} \\
\text { UH-LA }\end{array}$ & $\begin{array}{l}\text { <ridged plains (LH); } \\
\text { =Tharsis flows (UH-LA); } \\
\text { >Medusae Fossae material } \\
\text { (MA-UA) }\end{array}$ \\
\hline Fretted channeis & UN-UH & UN-MA ${ }^{(18)}$ & $\begin{array}{l}\text { Sintercrater plains (UN); } \\
\text { =ridged plains (LH); } \\
\text { zoutflow channels (UH) }\end{array}$ \\
\hline Small runoff channels & UN(or lower) & $\mathrm{UN}^{(16)}$ & $\begin{array}{l}\text { <cratered plains (MN); } \\
\text { >ridged plains (LH) }\end{array}$ \\
\hline $\begin{array}{l}\text { Long, sinuous channels (e.g., } \\
\text { Ma'adim) }\end{array}$ & UN-LH & $\mathbf{L H}^{(16)}$ & Sintercrater plains (UN) \\
\hline Cerberus Rupes & D. Fr & $\begin{array}{l}\text { zcture Systems } \\
\text { none }\end{array}$ & $\begin{array}{l}\text { =western Amazonis channel } \\
\text { (UA) }\end{array}$ \\
\hline Northeast of Ascraeus Mons & MA-UA & $\begin{array}{l}\text { MA-UA } A^{(14)}, \text { MA- } \\
\mathrm{UA}^{(17]}\end{array}$ & $=$ Tharsis flows (MA-UA) \\
\hline South of Ceraunius Tholus & LA-MA & $\begin{array}{l}\mathrm{LA}^{(17)} \\
\mathrm{MA}^{(14)}, \text { LA- }\end{array}$ & $=$ Tharsis flows (LA-MA) \\
\hline $\begin{array}{l}\text { Elysium Fossae } \\
\text { Eastern Memnonia Fossae }\end{array}$ & UH-LA & $\begin{array}{l}\text { none } \\
\text { LA }^{(14)}, U H-L A^{(17)}\end{array}$ & $\begin{array}{l}=\text { Elysium flows (UH-LA) } \\
=\text { Tharsis flows (UH-LA) }\end{array}$ \\
\hline $\begin{array}{l}\text { Eastem Memnonia Fossae } \\
\text { Daedalia Planum }\end{array}$ & UH-LA & $L^{L H}-\mathbf{L A}^{(17)}{ }^{(14)}$, UH- & $=$ Tharsis flows (UH-LA) \\
\hline $\begin{array}{l}\text { East of Ceraunius Tholus } \\
\text { Labeatis Fossae }\end{array}$ & UH-LA & LH-LA ${ }^{(14)}, L_{A^{(17)}}$ & \\
\hline $\begin{array}{l}\text { Labeatis Fossae } \\
\text { Fortuna Fossae }\end{array}$ & & $\mathrm{UH}^{(i-1)}, \mathrm{UH}^{(-1)}$ & $\begin{array}{l}=\text { Tharsis tlows (UH) } \\
>\text { Tharsis flows (MA) }\end{array}$ \\
\hline Alba and Tantalus Fossae & LH-LA & $\begin{array}{l}\mathrm{LH}^{(2)}{ }^{(20)} \mathrm{LH}-\mathrm{L} A^{(8)} \\
\mathrm{UH}^{(8)}\end{array}$ & $\begin{array}{l}<\text { Ceraunius Fossae (UN); } \\
=\text { Alba Patera flows (LH-LA); } \\
\text { >smooth plains (LA) }\end{array}$ \\
\hline $\begin{array}{l}\text { Noctis Labyrinthus } \\
\text { Tempe and Mareotis Fossae }\end{array}$ & $\begin{array}{l}\text { LH-UH } \\
\text { LH-UH }\end{array}$ & $\begin{array}{l}\mathbf{U H}^{(8)} \\
\mathrm{UN}-\mathrm{LH}^{(1)}, \mathbf{M N}^{(20)}\end{array}$ & $\begin{array}{l}\text { ZSyria Planum flows (UH) } \\
\text { Sridged plains (LH); =Tempe } \\
\text { Fossae flows (LH-UH) }\end{array}$ \\
\hline Ulysses Fossae & LH & $\begin{array}{l}\text { UN-LH }{ }^{(7)}, \text { LH- } \\
\mathrm{UH}^{(14)}\end{array}$ & $\begin{array}{l}\text { >Olympus aureoles (LA), } \\
\text { Tharsis flows (MA) }\end{array}$ \\
\hline Uranius Fossae & LH & LH-UH ${ }^{(14)}$ & $>$ Tharsis flows (UH) \\
\hline Western Memnonia Fossae & LH & LH-UH ${ }^{(14)}$ & $>$ Tharsis flows (UH) \\
\hline Icaria Fossae & LH & UN-LHH(14) & $=$ intercrater plains (LH) \\
\hline Thaumasia Fossae & LH & UN-LH ${ }^{(14)}$ & $\begin{array}{l}\text { =intercrater plains (LH); } \\
\text { >Syria Planum flows (UH) }\end{array}$ \\
\hline $\begin{array}{l}\text { Nia Fossae } \\
\text { Valles Marineris, }\end{array}$ & LH (or higher) & $\mathbf{L H}^{(14)}$ & <ridged plains (LH) \\
\hline Main development & LH & none & $\begin{array}{l}\text { Sridged flows (LH); > layered } \\
\text { deposits and outflow channels } \\
\text { (UH) }\end{array}$ \\
\hline Subsequent faulting & UH-UA & none & $\begin{array}{l}\text { layered deposits (UH); } \\
=\text { landslides (MA-UA) }\end{array}$ \\
\hline Sirenum Fossae & UH-LH & $\mathrm{UN}-\mathrm{LH}^{(14)}, \mathrm{UN}^{(20)}$ & $>$ Tharsis flows (UH) \\
\hline Nectaris Fossae & & $\mathrm{UN}-\mathrm{LH}^{(14)}$ & $\begin{array}{l}\text { <cratered plains (MN); } \\
\text { >ridged plains }(\mathrm{LH})\end{array}$ \\
\hline Ceraunius Fossae & UN & UN-L.H ${ }^{(14)}$ & >Alba Patera flows (LH) \\
\hline Claritas Fossae (north) & UN & $\mathbf{U N}^{(14)}$ & $\begin{array}{l}\text { <south Claritas Fossae (MN); } \\
\text { > Syria Planum flows (UH), } \\
\text { Noctis Labyrinthus (LH-UH) }\end{array}$ \\
\hline Noctis Fossae & UN & $\mathrm{UN}^{(14)}$ & $\begin{array}{l}\text { >Noctis Labyrinthus (LH- } \\
\text { UH) }\end{array}$ \\
\hline Faults east of Elysium Planitia & UN & $\mathbf{L N}^{(20)}$ & $\begin{array}{l}\text { <knobby terrain (MN?); } \\
\text { >ridged plains (LH) }\end{array}$ \\
\hline Coracis Fossae & MN-LH & $\mathrm{MN}^{(14)}$ & $\begin{array}{l}\text { <basement material (LN); } \\
\text { > Syria Planum flows (UH) }\end{array}$ \\
\hline Acheron Fossae & MN & $\mathrm{UN}^{(8)}$ & >intercrater plains (UN) \\
\hline Claritas Fossae (south) & $\mathbf{M N}$ & $\mathrm{MN}^{(14)}, \mathrm{MN}^{(20)}$ & $\begin{array}{l}\text { <basement material (LN); } \\
\text { >north Claritas Fossae (UN) }\end{array}$ \\
\hline $\begin{array}{l}\text { Melas Fossae } \\
\text { Basin faults }\end{array}$ & $\begin{array}{l}\text { MN } \\
\text { LN-MN }\end{array}$ & $\begin{array}{l}\text { none } \\
\mathrm{LN}-\mathrm{MN}^{(20)}\end{array}$ & $\begin{array}{l}\text { >intercrater plains (UN) } \\
\geq \text { cratered terrain (MN); } \\
\text { >intercrater plains (UN) }\end{array}$ \\
\hline
\end{tabular}


TABLE 5. (continued)

\begin{tabular}{|c|c|c|c|}
\hline Unit or Feature & $\begin{array}{l}\text { Stratigraphic } \\
\text { Position }\end{array}$ & Cited Crater Ages & Key Geologic Relations \\
\hline Lyot & E. & $\begin{array}{c}\text { Impact Basins } \\
\text { none }\end{array}$ & 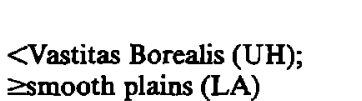 \\
\hline Lowell & LH & none & $\begin{array}{l}\text { <intercrater plains (UN-LH); } \\
\text { >Thaumasia Fossae (LH) }\end{array}$ \\
\hline Most impact basins & LN-MN & none & $\begin{array}{l}\text { Zcratered plains (MN); } \\
\text { >intercrater plains (UN) }\end{array}$ \\
\hline South polar & LN & none & $>$ cratered plains $(\mathrm{MN})$ \\
\hline Argyre & LN & $\mathrm{MN}^{(8)}$ & >cratered plains (MN) \\
\hline Hellas & LN & $\mathbf{M N}^{(8)}$ & >cratered plains (MN) \\
\hline Isidis & LN & $\mathbf{L N}^{(8)}$ & >cratered plains (MN) \\
\hline
\end{tabular}

\begin{abstract}
"Stratigraphic position" is determined by crater counts and geologic relations; $N=$ Noachian, $H$ = Hesperian, $\mathbf{A}=$ Amazonian, $\mathbf{L}=$ Lower, $\mathbf{M}=$ Middle, $\mathrm{U}=$ Upper. "Cited crater age" is mostly deduced from crater counts; includes geologic relations from some studies; counts may be for only part of the unit or feature; footnote is for reference below. "Key geologic relations" are those most helpful in establishing age; includes ages more detailed than in table (e.g., Tharsis flows are subdivided); $<$ means younger than, = means contemporaneous with, and > means older than.

References: (1) Hartmann et al. [1981]; (2) Dial [1984]; (3) Lucchitta [1979]; (4) Masursky et al. [1977]; (5) Squyres [1978]; (6) Scott and Tanaka [1982]; (7) Hiller et al. [1982]; (8) Table 3; (9) Condit [1978]; (10) Greeley and Spudis [1981]; (11) Witbeck and Underwood [1984]; (12) Soderblom et al. [1974]; (13) Plescia and Saunders [1979]; (14) Plescia and Saunders [1982]; (15) Gurnis [1981]; (16) Carr and Clow [1981]; (17) Scott and Tanaka [1981b]; (18) Neukum and Hiller [1981]; (19) Masursky et al. [1986]; (20) Wichman and Schultz [1986].
\end{abstract}

places more than half the craters are embayed by local deposits. Densities of fresh, unembayed craters greater than about $4 \mathrm{~km}$ in diameter on Upper Noachian intercrater plains are consistently lower than densities of similarly sized craters on Middle Noachian terrain [Tanaka, 1985a].

Also during the Middle Noachian (and possibly earlier), Acheron, Claritas, Coracis, Nectaris, and Melas Fossae and the broad, arcuate ridge along the south edge of Solis and Sinai Plana (Figure 1) were formed.

\section{Late Noachian Epoch}

During this epoch an early intercrater unit was emplaced that overlies much of the older Martian highland material. Only larger exposures are mapped (Figure 3); many smaller patches are not shown. These materials are relatively smooth but have channels and wrinkle ridges in places. Crater densities for this unit range from $N(16)=30$ to 100 and average about 90 in the western part of Mars.

The intercrater deposits are thicker in some areas than others, and crater densities are highly variable; many exposed craters are embayed. The distribution of craters greater than $8 \mathrm{~km}$ in diameter is intermediate in form between that of earlier (lognormal) and later (power-law) distributions. The sizefrequency distributions of craters about 2 to $4 \mathrm{~km}$ in diameter are about the same for Middle Noachian to Lower Hesperian surfaces [Tanaka, 1985a]. Furthermore, a density map of 0.6 to $1.2 \mathrm{~km}$ craters for most of Mars by Soderblom et al. [1974, Figure 5] indicates densities that correspond to Amazonian and Hesperian ages. The lack of regions having high densities of small craters indicates that nearly complete obliteration of these craters occurred during the Late Noachian and possibly earlier as well. However, by Early Hesperian time, surfaces were produced that show no indication of obliteration of craters larger than $1 \mathrm{~km}$ in diameter. Chapman and Jones [1977, p. 525] have also indicated that an episode of crater obliteration occurred during an intermediate stage of Martian history, on the basis of distributions of fresh to degraded craters in the 5- to 15$\mathrm{km}$-diameter size range. The obliteration of small craters may be a result of easily eroded surface materials, mantling by eolian and volcanic deposits, and wind and water erosion produced by a thicker atmosphere and warmer surface temperature.

High-resolution images of the cratered and intercrater plains show that significant erosion or burial occurred in most places sufficient to obliterate preexisting kilometer-size craters. Small but densely arrayed channels dissect cratered terrain and intercrater plains material and predate the ridged plains material; they appear to have formed by water runoff [Pieri, 1976; Carr and Clow, 1981]. Larger runoff channels such as Ma'adim, AlQahira, and Nirgal Valles (Figure 1) also cut the cratered plains and were formed at about the same time as the smaller channels.

Faulting was extensive in the Tharsis region during the Late Noachian Epoch, continuing at Claritas, Coracis, and Nectaris Fossae and commencing at Noctis and Ceraunius Fossae. Most faults are oriented radially to Syria Planum [Plescia and Saunders, 1982]. More than 30 mountains (not shown) of possible volcanic origin that may have formed during this epoch occur from Claritas and Thaumasia Fossae west to Sirenum Fossae [Scott and Tanaka, 1981a], at Nectaris Fossae [Roth et al., 1980], and at other highland areas (including Apollinaris Patera). Fissure volcanism along Acheron Fossae produced lava fill within the arcuate structure [Scott and Tanaka, 1986]. Although their age is not precisely established, Valles Marineris may have been initiated by faulting at this time. East of Elysium Planitia, faults that bound wide grabens cut the knobby, degraded cratered terrain and the grabens are embayed by Lower Hesperian ridged plains material; these faults may have formed during the Late Noachian.

\section{Early Hesperian Epoch}

The Lower Hesperian Series referent is the ridged plains material, which is characterized by smooth surfaces marked by long, sinuous wrinkles ridges. This unit is extensive and covers 
the following areas: (1) part of the southern edge of the northern plains; (2) plains between Elysium and Amazonis Planitiae; (3) Hellas Planitia; and (4) many high plains such as Lunae, Sinai, Syrtis Major, Hesperia, and Malea Plana (Figure 1, Plate 1). Ridged plains also occur in small patches in craters and in intercrater highland areas. In places, the Vastitas Borealis Formation appears to embay and encroach on the ridged plains material; the formation perhaps results from modification of ridged plains material. For example, in southern Utopia Planitia, the ridged plains material is locally hummocky and knobby. Hence much of the Vastitas Borealis Formation may have originally been ridged plains material emplaced by voluminous eruptions of low-viscosity, mafic lava [Greeley and Spudis, 1981]. Possible local sources of the ridged plains material include Hadriaca, Tyrrhena, Amphitrites, and Peneus Paterae (Figure 1).

By Early Hesperian time, the cratering rate was much reduced from that of the Noachian heavy bombardment [Hartmann et al., 1981, Figure 8.6.3]. Stratigraphic relations (Table 5) suggest that the double-ring impact basin Lowell is Early Hesperian in age. Cumulative size-frequency distributions of craters more than $1 \mathrm{~km}$ in diameter on most pristine Martian surfaces generally follow a power law, similar to the distribution of craters on the lunar maria [Hartmann, 1978]. Densities of craters larger than $5 \mathrm{~km}$ in diameter for materials of this epoch are most reliable at $5 \mathrm{~km}$ diameter and generally range from 125 to 200 for the ridged plains referent. On Malea Planum, ridged plains material has a slightly higher crater density [Hartmann et al., 1981]; however, some of the craters within the unit appear embayed by the ridged plains material. Counts of craters larger than $4 \mathrm{~km}$ in diameter on Lunae Planum suggest that the ridges are about the same age as the plains material surrounding the ridges [Tanaka, 1982], but the ridges have a higher density of craters 2 to $4 \mathrm{~km}$ in diameter than the plains. Burial of interridge areas is evidenced in eastern Sinai Planum, where high-resolution images show lava flows originating from the Syria Planum region.

Intense erosion of cratered terrain and intercrater plains in the northern lowlands and along the highland-lowland boundary scarp preceded emplacement of ridged plains material. Deuteronilus and Protonilus Mensae (large polygonal mesas formed by development of fretted channels in highlands along the highland-lowland scarp) were formed after deposition of Upper Noachian intercrater plains material (some of which has wrinkle ridges), but they are embayed by ridged plains. This stratigraphic relation is also found in other areas along the highland-lowland scarp and around highland remnants in Utopia, Elysium, and western Amazonis Planitiae. The fretted channels within the mensae appear to be structurally controlled [Sharp and Malin, 1975] and related to ancient impact basins in places [Schultz et al., 1982]. The rim of Hellas impact basin generally has high relief but is absent where covered by ridged plains material along the northeast and south edges. Burial alone cannot explain this absence, because the ridged plains surface is found well below adjacent basin-rim material. In many other localities, embayments of highly degraded remnants of highland terrain by ridged plaips material show that intense degradation preceded the formation of ridged plains.

Several large volcanic loci that either were coeval with or immediately postdated ridged plains material produced extensive complexes late in the Early Hesperian Epoch. These centers include apparent calderas on Syrtis Major Planum that produced large sheet flows and were contemporaneous with a late stage of wrinkle-ridge formation [Schaber, 1982]; probable calderas, volcanoes, and tectonic depressions in Tempe Fossae [Scott, 1982]; and Alba Patera, which produced its northern and eastern distal flows during this time [Dial, 1984]. Flows of this epoch also may have occurred around Tharsis Montes, but they have been obscured by younger flows and their morphologic character destroyed by fractures.

The Noctis Labyrinthus-Valles Marineris rift system developed to a large extent during the Early Hesperian Epoch. Also, extensive fractures formed on highland surfaces surrounding most of the Tharsis region at Alba, Tantalus, Mareotis, Tempe, Ulysses, Uranius, western Memnonia, Sirenum, Icaria, and Thaumasia Fossae. Many of these fractures are radial to Syria Planum, and the youngest surfaces that they cut have counts of $N(5)=219$ to 115 [Plescia and Saunders, 1982]. This episode of rifting and faulting was perhaps the most intense in Martian history.

\section{Late Hesperian Epoch}

The Upper Hesperian referent, the Vastitas Borealis Formation [Scott and Tanaka, 1986], covers most of the northern lowlands in Acidalia, Isidis, Elysium, and Utopia Planitiae and all lowland areas north of lat $55^{\circ} \mathrm{N}$ (Figures 1 and 2). Densities of craters larger than $5 \mathrm{~km}$ in diameter for the formation are remarkably uniform, ranging from $N(5)=65$ to 110 and averaging about $\mathrm{N}(5)=75$ [Dial, 1984; Witbeck and Underwood, 1984; Table 3], suggesting that most of its surface formed in a relatively short time. Counts for craters larger than $2 \mathrm{~km}$ in diameter $(\mathrm{N}(2))$, however, are erratic. They are generally lower than expected from a -2 power-law projection from $\mathrm{N}(5)$ counts and are latitude dependent. North of lat $55^{\circ} \mathrm{N}$, $\mathrm{N}(2)=150-250$ and south of lat $55^{\circ} \mathrm{N}, \mathrm{N}(2)=250-375$ (Table 3). This trend suggests that the craters farther north are composed of easily erodible material or were subjected to greater erosive processes, or both. Although the Vastitas Borealis Formation is confined to the northern plains, knobby material resembling the knobby member of the formation was produced in the center of Hellas Planitia at nearly the same time [N(5) = about 60].

Although formation of the intercrater plains material had nearly ceased, activity at many large volcanic regions on Mars commenced during this epoch, according to crater counts of the vent areas and lava flows that emanate from these vents. These flows have lobate scarps and leveed channels and closely resemble lava flows on Earth and the moon [Schaber et al., 1978]. Volcanoes and lava flows were emplaced at the southwest and northeast ends of the Tharsis swell; in plains west of Alba Patera; and at Syria Planum, Tempe Terra, Elysium Planitia, Ceraunius Fossae, and Dorsa Argentea. Possible cinder cones in the northern plains [Frey et al., 1979] are probably also Upper Hesperian. The complex, overlapping, lobate lava flows common to many of these areas overlie ridged plains material. Most of these surfaces retain craters larger than $1 \mathrm{~km}$ in diameter [Neukum and Wise, 1976; Scott and Tanaka, 1981b] except for the Hesperian flows north of Alba Patera, whose crater counts (Table 3 ) indicate obliteration of small ( $<5 \mathrm{~km}$ diameter) craters.

Fracturing was intense at Alba and Tantalus Fossae, but weak or absent elsewhere. The faults produced are dominantly radial to Pavonis Mons and have crater densities of $N(5)=115$ to 70 [Plescia and Saunders, 1982]. They occur primarily on the 
lower flanks of the Tharsis swell at Labeatis, Tempe, Mareotis, and eastern Memnonia Fossae and on southern Daedalia Planum. Rifting and collapse continued at Noctis Labyrinthus and Valles Marineris, cutting into Syria Planum flows and ridged plains material [Scott and Tanaka, 1986]. Arcuate faults partly buried by Tharsis flows at Fortuna Fossae may form part of a large volcanotectonic feature of about Late Hesperian age.

Deep erosion in the south polar highlands formed the cavi terrain (plateaus marked by deep, irregular pits), cutting into extensive lobate and sheetlike deposits of probable lava-flow origin (Dorsa Argentea flows) of Late Hesperian age and older [Tanaka and Scott, 1987; Tables 3, 5].

Crater counts made by Masursky et al. [1977] and Neukum and Hiller [1981] of the outflow-channel floors indicate a wide range of ages. However, Carr and Clow [1981] noted that only crater counts of deeply scoured channel surfaces may be valid; smooth or lightly eroded surfaces may yield crater ages that reflect resurfacing periods rather than channeling episodes. Counts for the deeply scoured surfaces and gradational contacts of the flood-plain material with the Vastitas Borealis Formation in Chryse Planitia suggest that outflow-channel activity was mostly restricted to the Late Hesperian Epoch. The channels originated from chasmata and chaotic highland terrain. If the chaotic terrain was formed by collapse due to withdrawal of subsurface volatiles, as is commonly believed, it is the same age as the channels. Juventae and Ganges Chasmata contain layered deposits that now appear as streamlined, moderate-size (tens of kilometers across), rounded hills rising above the valley floors, showing that, during Late Hesperian time, deposition of layered material followed channel formation. In channels east of Valles Marineris and in Kasei Valles, multiple terrace levels in the channels and chaotic terrain suggest multiple stages of channel formation. Flood-plain materials from the channels fan out into Chryse Planitia and grade into the lowermost member of the Arcadia Formation in western Acidalia Planitia [Scott and Tanaka, 1986]. The smooth plains here appear to bury remnants of sinuous channels. The Mangala Valles outflowchannel system, which largely originates from a fracture in the highlands west of Daedalia Planum, debouches into southern Amazonis Planitia, cuts ridged plains material, and appears contemporaneous with Upper Hesperian-Lower Amazonian Tharsis flows [Masursky et al., 1986; Scott and Tanaka, 1986]. Thus the Late Hesperian Epoch marks the major period of outflow-channel activity on Mars.

Remnants of smooth plains deposits are superposed on the ridged plains material of Malea Planum and appear to occur in low areas (ringed by wrinkle ridges) or below ejecta blankets of large impact craters. The deposits postdate the ridged plains and may in part be Late Hesperian in age, as indicated by the apparent density of superposed craters.

\section{Early Amazonian Epoch}

The Lower Amazonian referent is moderately cratered smooth plains material in southern Acidalia Planitia (Figures 1 and 2). This unit also occurs in patches in Amazonis, Arcadia, and southern Elysium Planitiae and extends as far north as lat $68^{\circ} \mathrm{N}$, north of Alba and Tantalus Fossae. A similar unit occurs in the lowlands north of Protonilus Mensae (R. Greeley and J. E. Guest, unpublished data, 1986). Crater counts in southern Acidalia Planitia yield about $\mathrm{N}(5)=55$ and $\mathrm{N}(2)=300$ to 450 . For eastern Acidalia Planitia, Witbeck and Underwood [1984] reported $N(5)=100$ and $N(2)=420$. In northeastern Arcadia Planitia, $N(2)$ is about 150 to 200 . Variations in the crater counts may in part be attributable to inclusion of other units in the areas counted and to obliteration of smaller craters. The unit locally consists of lava flows [Scott and Tanaka, 1986] but is mantled in most areas. Some of the unit, particularly in Acidalia Planitia and north of Tempe Fossae, may be composed of eolian or alluvial sediments [Witbeck and Underwood, 1984].

Stratigraphic relations and crater counts [Plescia and Saunders, 1979; Scott and Tanaka, 1981b] indicate that lava flows were emplaced at this time, mostly from the large shield volcanoes and fissures around Tharsis Montes, Alba Patera, and Elysium Mons. A few of the smaller Tharsis volcanoes were also active. Some of the tharsis flows entered northwestern Kasei Valles [Scott and Tanaka, 1986]. Fault activity was localized around Tharsis volcanoes in southern Daedalia Planum, eastern Memnonia Fossae, and south of Uranius Patera; around Alba Patera at Alba and Tantalus Fossae; and on the flanks of Elysium Mons, forming Elysium Fossae [Mouginis-Mark et al., 1984].

The Olympus Mons aureoles were emplaced about this time. One of the aureoles overlies Lower Hesperian terrain cut by Ulysses Fossae, and all of the aureoles underlie Upper Amazonian lava flows of Olympus Mons. The lowermost aureoles west of Olympus Mons are embayed by Middle Amazonian lava flows and plains material. Crater counts by Hiller et al. [1982] indicate an Early Amazonian age for the aureoles; however, the crater counts may be unreliable because of the degraded nature of the aureoles' surfaces [Morris, 1982]. Widely varying explanations have been postulated for the aureoles, but most workers ascribe origins related to volcanism [McCauley et al., 1972; Hodges and Moore, 1979; Morris, 1982] or to gravity slides on the flanks of Olympus Mons [Lopes et al., 1980; Francis and Wadge, 1983; Tanaka, 1985b]. In either case, the aureole material must somehow be a product of volcanism in the Olympus Mons area. The relative age of formation of the volcano's basal scarp is loosely defined and may be about the same as that of the aureoles. Thus development of Olympus Mons began during this epoch or earlier, and the volcano had probably attained most of its present size by the end of the epoch.

Some of the floor materials in Valles Marineris are younger than middle Hesperian layered deposits and older than Middle to Upper Amazonian slide deposits. The floor materials are moderately cut by the faults of small grabens and are relatively uneroded. During the Hesperian Period, major faulting, filling, and erosion occurred within the Noctis Labyrinthus-Valles Marineris system, indicating that geologic activity was greatly reduced during the Lower Amazonian Epoch. Local side canyons in western Valles Marineris were formed by headward sapping of plateau materials that include the Upper Hesperian Syria Planum Formation. Many of these side canyons appear to be controlled by buried faults. At Mangala Valles, crater counts and stratigraphic relations indicate that narrow channels dissected the floors of earlier, broad outflow channels during the Early Amazonian [Masursky et al., 1986]. Also during the Early Amazonian, large floods (producing Hrad, Tinjar, and Granicus Valles), debris or pyroclastic flows [Christiansen and Greeley, 1981; Tanaka and Scott, 1986], and lava flows emanated from northwestern Elysium Fossae into Utopia Planitia.

Even though the earlier cratering rate was now greatly reduced, the peak-ring basin Lyot north of Deuteronilus Mensae was 
formed in the rocks of the Vastitas Borealis Formation. Lyot's extensive secondary craters occur on surrounding highland and lowland surfaces and are buried by Early Amazonian smooth plains material and debris aprons [Ferguson and Lucchitta, 1985; R. Greeley and J. E. Guest, unpublished data, 1986]. Therefore Lyot impact basin is about Early Amazonian in age-the youngest impact basin on Mars.

\section{Middle Amazonian Epoch}

The referent for the Middle Amazonian Epoch consists of lava flows in Amazonis and southern Arcadia Planitiae (Figures 1 and 3), which were recently mapped as members 3 and 4 of the Arcadia Formation [Scott and Tanaka, 1986]. The flows generally form smooth plains and have subdued scarps that appear lightly mantled [Scott and Tanaka, 1986]. Similar plains occur in southern Elysium Planitia. Crater counts for eastern Amazonis Planitia by Hiller et al. [1982] yielded $\mathrm{N}(2)=70$; Tharsis flows of this epoch have $\mathrm{N}(2)=90$ to 120 [Scott and Tanaka, 1981 b; Plescia and Saunders, 1982]. During the Middle Amazonian Epoch, volcanism was largely restricted to the Tharsis Montes, Olympus Mons, the northem plains, and perhaps to the highland-lowland boundary between the Tharsis and Elysium regions.

A sequence of thick, mostly light-colored material was deposited along the highland-lowland boundary scarp in southern Amazonis Planitia between Ulysses Fossae and Apollinaris Patera and in southern Elysium Planitia. Scott and Tanaka [1982] subdivided these deposits into seven units having crater counts ranging from $\mathrm{N}(1)=65$ to 730 , which indicate a Middle to Late Amazonian age span. They were interpreted to be either paleopolar deposits [Schultz and Lutz-Garihan, 1981] or interbedded ignimbrite and lava-flow deposits [Scott and Tanaka, 1982]. Scott and Tanaka [1986] remapped them into three members of the Medusae Fossae Formation of which the lower and middle members were considered to have been emplaced during the Middle Amazonian Epoch.

Crater densities indicate that some of the large landslides within Valles Marineris [Lucchitta, 1979] were emplaced during this epoch and in the Late Amazonian. A few normal faults oriented parallel to the valley walls cut the landslides [Blasius et al., 1977] and are obviously recent.

Debris aprons in Protonilus Mensae and debris flows in fretted channels have crater densities within the range of $\mathrm{N}(1)=200$ to 500 [Masursky et al., 1977; Squyres, 1978], which are consistent with the age of this series. However, the available crater statistics are highly uncertain and somewhat older or younger ages are possible. Some of the debris aprons may still be active [Squyres, 1978].

\section{Late Amazonian Epoch}

The referent is a flood-plain deposit in southern Elysium Planitia that apparently originated from Cerberus Rupes; it extends into a large, smooth-floored outflow channel in western Amazonis Planitia [Tanaka and Scott, 1986]. The unit is marked by widely scattered craters generally $<1 \mathrm{~km}$ in diameter.

Small lava-flow units on the flanks of the Tharsis Montes and Olympus Mons and smooth plains material in southern Arcadia Planitia have crater densities of $N(1)<160$ (Tables 3 and 5). Other uncratered, possibly volcanic, deposits occur along faults and overlie landslides in Valles Marineris [Lucchitta, 1985]. Minor structures associated with Tharsis volcanoes that formed during this epoch include caldera and circumferential flank faults on the Tharsis Montes and Olympus Mons and recent faults in central Valles Marineris [Blasizs et al., 1977]. Minor faulting also occurred in southern Elysium Planitia, forming long, arcuate, west-northwest-trending fractures (Cerberus Rupes) that appear to cut Upper Amazonian plains material in places. The channel material that is the referent for this series appears to have issued from these fractures [Tanaka and Scott, 1986]

The layered deposits in the north polar region, forming Planum Boreum, are uncratered at available image resolutions [Dial, 1984]. On the south polar layered deposits making up Planum Australe, one fresh-appearing 20-km-diameter crater is found; other craters are subdued because they either underlif the layered deposits or are superposed on layered deposits that were subsequently buried. Interpretations of the origin of the layered deposits and of the arcuate troughs that transect them are important in determining the age of the deposits. Although the paucity of craters indicates that the deposits' surfaces are less than a few million years old, the material is possibly reworked periodically and may have accumulated over a much longer time [Carr, 1982].

At both poles, the layered deposits are superposed by residual ice caps. Extents, compositions, and depositional rates of the ice caps probably change gradually because of oscillations of the polar heat budget and dust-storm activity. These oscillations are governed by Mars' rotational obliquity (50,000-year period) and orbital eccentricity (2,000,000-year period). Due to seasonal dust-storm activity, perennial water ice is presently retained at the north pole [Kieffer et al., 1976]. Water ice may also be present at the south pole, but it cannot be detected because the $\mathrm{CO}_{2}$ seasonal cap does not completely dissipate. Also, dust deposition is greater in the north polar region [Pollack et al., 1979]. A dust mantle as much as $200 \mathrm{~m}$ thick [Squyres, 1979] apparently exists on the north circumpolar plains but is absent or very thin in the south polar region.

Extensive dunes surround the north pole [Tsoar et al., 1979; Dial, 1984] but are sparse in equatorial and south polar regions, where they generally occur within impact craters and valleys and along the bases of scarps. Although most of the dunes may be active, a large, relatively stable set of dunes adjacent to north polar layered deposits in Olympia Planitia (Figure 1) may be at lease several million years old [Breed et al., 1979], and thus may have endured through the periodic climatic changes of Mars caused by orbital and rotational dynamics. The sand (or sand-size aggregates [Greeley et al., 1982]) probably was derived from sources such as the Vastitas Borealis Formation [Tsoar et al., 1979], the polar layered deposits [Breed et al., 1979], or fluvial deposits formed by channeling in the northern lowlands [Mc Cauley et al., 1980].

Landslide materials along the basal scarp of Olympus Mons are superposed on Upper Amazonian lava flows. Many of the landslides in Valles Marineris lack craters and therefore may also be Upper Amazonian. Concentrically ridged debris blankets on the western flanks of the Tharsis Montes are about the same age as the volcanoes' youngest flows [Scott and Tanaka, 1981b]. The mode of origin of the blankets is unknown. Lucchitta [1981] proposed that they may be recessional moraines of former ice caps. Also, local debris aprons and flows in the fretted channels and mensae, in Valles Marineris, and along other high-latitude scarps are sparsely cratered and were probably active during the Late Amazonian.

\section{SUMMARY AND CONCLUSIONS}

A detailed analysis of the global stratigraphy of Mars, supported by new and revised geologic maps based on the 
recently completed Viking 1:2,000,000-scale photomosaic series of the planet, has been presented. Published crater counts and stratigraphic analyses were used in part, but new work was centered on geologic units and features whose relative ages were not well known. The geologic history of Mars has been summarized on geologic maps showing eight time-stratigraphic divisions that include all surface materials.

The three major time-stratigraphic periods of Mars-the Noachian, Hesperian, and Amazonian Systems-developed by Scott and Carr [1978] from Mariner 9 mapping have been subdivided into eight epochs, based on the eight corresponding time-stratigraphic series of deposits. Their inferred events are summarized as follows:

(1) Early Noachian Epoch-Major impact-basin formation (Isidis, Hellas, Argyre, and south polar); formation of the northern lowlands.

(2) Middle Noachian Epoch-Cratered terrain formation; lognormal cratering distribution; faulting in south Tharsis.

(3) Late Noachian Epoch-Intercrater plains resurfacing; reduced cratering flux, transition to power-law cratering distribution; intense erosion and runoff-channel development; beginning of intense faulting centered at Syria Planum; formation of highland volcanoes and ridges.

(4) Early Hesperian Epoch-Ridged plains emplacement, particularly at Lunae, Syrtis Major, Hesperia, and Malea Plana, and in northern lowlands; burial and degradation of lowland cratered terrain; extensive faulting centered at Syria Planum; major rifting at Noctis Labyrinthus-Valles Marineris; Alba Patera and Tempe Terra volcanism; fretted channel development; formation of Lowell impact basin.

(5) Late Hesperian Epoch-Resurfacing of northern plains (by complex of lava flows, eolian deposits, and alluvial sediments), then erosion of these plains; major volcanism at Tharsis Montes, Alba Patera, Terra Tempe, Syria Planum, Elysium Planitia, Ceraunius Fossae, and Dorsa Argentea; outflow-channel development by water flooding; deposition of Valles Marineris layered deposits; waning Tharsis tectonism; deposition of south polar unconsolidated material.

(6) Early Amazonian Epoch-Lava flows form northern smooth plains; local volcanic flows at Tharsis Montes, Alba Patera, and Elysium Mons; formation of Olympus Mons aureoles; formation of Lyot impact basin.

(7) Middle Amazonian Epoch-Continued accumulation of lava flows in northern plains, particularly in Amazonis Planitia; volcanism at Tharsis Montes and Olympus Mons; emplacement of thick, poorly consolidated material of Medusae Fossae Formation; development of debris flows and aprons surrounding Deuteronilus and Protonilus Mensae; landslides in Valles Marineris.

(8) Late Amazonian Epoch-Formation of broad flood plain in southern Elysium Planitia; youngest lava flows at Tharsis Montes and Olympus Mons; most recent resurfacing of northern plains; reworking of polar layered, dune, mantle, and ice deposits into present form; debris aprons at Tharsis Montes and mensae; landslides at Olympus Mons and in Valles Marineris.

The evolution of tectonism and volcanism on Mars, in general, appears to be related to temporal and spatial changes in lithospheric thickness or strength. In Noachian and Early Hesperian time, volcanism and tectonism were widespread, and large mass anomalies, such as impact craters and basins, were compensated isostatically [e.g., Sjogren, 1979]. However, in Late Hesperian and Amazonian time, global tectonism and volcanism waned and became centralized, and fractures and volcanic constructs occurred mostly in areas where the lithosphere was thin [Comer et al., 1985]. Gravimetry of Mars [Sjogren, 1979] indicates that gravity anomalies occur over younger mass features such as Tharsis Montes, Olympus Mons, Alba Patera, and Elysium Mons. Such features were possibly supported by an increased flexural rigidity (or thickness) of the lithosphere [Comer et al., 1985].

The Martian climatic and volatile histories are other important factors in the planet's geologic evolution. Fluvial activity was widespread during Noachian time, perhaps aided by a thicker, warmer atmosphere and a warmer surface that allowed surficial running water and perhaps even rain. In Hesperian time, however, runoff channels ceased to form. Instead, voluminous, water-rich aquifers in the highland regolith were tapped, producing the huge outflow channels that drained into the northern lowlands. Also during the Hesperian, and in the Amazonian, ground ice was apparently responsible for producing landslides, debris flows, channels, and other landforms. At present, subfreezing temperatures envelop the entire surface of the planet, and resurfacing is dominated by eolian processes. These processes are observed principally in the polar regions, where dust-storm and seasonal frost activities are strongest.

The absolute ages of the Martian epoch boundaries are model dependent and are largely uncertain. According to two models discussed in this paper, most geologic activity (within the Noachian and Hesperian Periods) occurred either during the first one billion years of surface history [Neukum and Wise, 1976; Neukum and Hiller, 1981] or during the first two billion years [Hartmann et al., 1981, Figure 8.6.3; this paper]. Other absolute-age models [e.g., Soderblom et al., 1974] generally suggest crater-flux histories intermediate between the Neukum and Wise and the Hartmann et al. models. A similar evolution of crater size-frequency distributions demonstrates the plausibility that impacts on the moon and Mars originated from the same population of planetesimals. As in the case of the moon, however, we will firmly resolve the absolute chronology for the Martian surface only after future missions return rock samples from selected areas for radioisotopic-age analysis.

Acknowledgments. I thank D. H. Scott, R. Greeley, and J. E. Guest for permission to use unpublished stratigraphic data and geologic maps on which parts of this paper, particularly the stratigraphic maps, ar based. M. H. Carr, L. A. Rossbacher, D. H. Scott, D. E. Wilhelms, and J. R. Zimbelman reviewed the manuscript and provided many helpful suggestions. M. F. Tuesink performed some of the crater counts presented, and N. K. Robertson and A. Wasserman digitized the stratigraphic maps. The research in this paper was supported by NASA Work Order W-15,814.

\section{REFERENCES}

Blasius, K. R., J. A. Cutts, J. E. Guest, and H. Masursky, Geology of the Valles Marineris: First analysis of imaging from the Viking 1 Orbiter primary mission, J. Geophys. Res., 82, 4067-4091, 1977.

Boyce, J. M., and N. E. Witbeck, Crater enlargement effects resulting from impact into subsurface volatiles on Mars (abstract), Geol. Soc. Amer. Abstr. Programs, 17, 530, 1985.

Breed, C. S., M. J. Grolier, and J. F. McCauley, Morphology and distribution of common' sand' dunes on Mars: Comparison with the Earth, J. Geophys. Res., 84, 8183-8204, 1979.

Carr, M. H., The Surface of Mars, Yale University Press, New Haven, 232 pp., 1981.

Carr, M. H., Periodic climate change on Mars: Review of evidence and effects on distribution of volatiles, Icarus, 50, 129-139, 1982.

Carr, M. H., and G. D. Clow, Martian channels and valleys: Their characteristics, distribution, and age, Icarus, 48, 91-117, 1981.

Carr, M. H., and G. G. Schaber, Martian permafrost features, $J$. Geophys. Res., 82, 4039-4054, 1977. 
Chapman, C. R., and K. L. Jones, Cratering and obliteration history of Mars, Ann. Rev. Earth Planet. Sci., 5, 515-540, 1977.

Christiansen, E. H., and R. Greeley, Mega-lahars (?) in the Elysium region, Mars (abstract), in Lunar and Planetary Science XII, pp. 138-140, Lunar and Planetary Institute, Houston, 1981.

Comer, R. P., S. C. Solomon, and J. W. Head, Mars: Thickness of the lithosphere from the tectonic response to volcanic loads, Rev. Geophys., 23, 61-92, 1985.

Condit, C. D., Distribution and relations of 4 to $10-\mathrm{km}$-diameter craters to global geologic units of Mars, Icarus, 34, 465-478, 1978.

Dial, A. L., Jr., Geologic map of the Mare Boreum area of Mars, Misc. Invest. Ser. Map 1-1640, U. S. Geol. Surv., Reston, 1984.

Ferguson, H. M., and B. K. Lucchitta, Crater Lyot and the dissection of the northern highland scarp of Mars (abstract), Reports of Planetary Geology and Geophysics Program-1984, pp. 577-579, NASA TM 87563, 1985.

Francis, P. W., and G. Wadge, The Olympus Mons aureole: Formation by gravitational spreading, J. Geophys. Res., 88, 8333-8344, 1983.

Frey, H., B. L. Lowry, and S. A. Chase, Pseudocraters on Mars, $J$. Geophys. Res., 84, 8075-8086, 1979.

Greeley, R., and P. D. Spudis, Volcanism on Mars, Rev. Geophys. Space Phys., 19, 13-41, 1981.

Greeley, R., R. N. Leach, S. H. Williams, B. R. White, J. B. Pollack, D. H. Krinsley, J. R. Marshall, Rate of wind abrasion on Mars, J. Geophys. Res., 87, 10009-10024, 1982.

Gurnis, M., Martian cratering revisited: Implications for early geologic evolution, Icarus, 48, 62-75, 1981

Hartmann, W. K., Martian cratering, 4, Mariner 9 initial analysis of cratering chronology, J. Geophys. Res., 78, 4096-4116, 1973.

Harmann, W. K., Relative crater production rates on planets, Icarus, $31,260-276,1977$.

Hartmann, W. K., Martian cratering V: Toward an empirical Martian chronology, and its implications, Geophys. Res. Lett., 5, 450-452, 1978.

Hartmann, W. K., R. G. Strom, S. J. Weidenschilling, K. R. Blasius, A. Woronow, M. R. Dence, R. A. F. Grieve, J. Diaz, C. R. Chapman, E. M. Shoemaker, and K. L. Jones, Chronology of planetary volcanism by comparative studies of planetary cratering, in Basaltic Volcanism on the Terrestrial Plonets, pp. 1049-1127, Pergamon, New York, 1981

Hiller, K. H., P. Janle, G. P. O. Neukum, J. E. Guest, and R. M. C. Lopes, Mars: Stratigraphy and gravimetry of Olympus Mons and its aureoles, J. Geophys. Res., 87, 9905-9915, 1982.

Hodges, C. A., and H. J. Moore, The subglacial birth of Olympus Mons and its aureoles, J. Geophys. Res., 84, 8061-8074, 1979.

Kieffer, H. H., S. C. Chase, Jr., T. Z. Martin, E. D. Miner, and F. D. Palluconi, Martian north pole summer temperatures: Dirty water ice, Science, 194, 1341-1344, 1976.

Lopes, R. M. C., J. E. Guest, and C. J. Wilson, Origin of the Olympus Mons aureole and perimeter scarp, Moon and Planets, 22, 221-234, 1980.

Lucehitta, B. K., Landslides in Valles Marineris, Mars, J. Geophys. Res., 84, 8097-8113, 1979.

Lucchitta, B. K., Mars and Earth: Comparison of cold-climate features, Iearus, 45, 264-303, 1981.

Lucchitta, B. K., Young volcanic deposits in the Valles Marineris, Mars (abstract), in Lunar and Planetary Science XVI, pp. 503-504, Lunar and Planetary Institute, Houston, 1985.

Masursky, H., J. M. Boyce, A. L. Dial, Jr., G. G. Schaber, and M. E. Strobell, Classification and time of formation of Martian channels based on Viking data, J. Geophys. Res., 82, 4016-4037, 1977.

Masursky, H., A. L. Dial, Jr., and M. E. Strobell, Geologic map of the Phoenicis Lacus quadrangle of Mars, Misc. Invest. Ser. Map I-896, U. S. Geol. Surt Reston, 1978.

Masursky, H., M. G. Chapman, A. L. Dial, Jr., and M. E. Strobell, Ages of rocks and channels in prospective Martian landing sites of Mangala Valles region (abstract), in Lunar and Planetary Science XVII, p. 520-521, Lunar and Planetary Institute, Houston, 1986.

MeCauley, J. F., M. H. Carr, J. A. Cutts, W. K. Hartmann, H. Masursky, D. J. Milton, R. P. Sharp, and D. E. Wilhelms, Preliminary Mariner 9 report on the geology of Mars, Icarus, 17, 289-327, 1972.

McCauley, I. F., C. S. Breed, and M. J. Grolier, The Gilf Kebir and the western desert of Egypt-insights into the origin of the north polar erg on Mars (abstract), Reports of Planetary Geology Program1980, pp. 312-313, NASA TM 82385, 1980.

McGill, G. E., Age and origin of large martian polygons (abstract), in Lunar and Planetary Science XVI, pp. 534-535, Lunar and Planetary Institute, Houston, 1985.

Milton, D. J., Geologic map of the Lunae Palus quadrangle of Mars, Misc. Invest. Ser. Map I-894, U. S. Geol. Surv., Reston, 1974.

Moore, H. J., Geologic map of the Sinus Sabaeus quadrangle of Mars, Misc. Invest. Ser. Map 1-1196, U. S. Geol. Surv., Reston, 1980.

Morris, E. C., Aureole deposits of the Martian volcano Olympus Mons, J. Geophys. Res., 87, 1164-1178, 1982.

Mouginis-Mark, P. J., L. Wilson, J. W. Head, S. H. Brown, J. L. Hall, and K. D. Sullivan, Elysium Planitia, Mars: Regional geology, volcanology, and evidence for volcano-ground ice interactions, Earth, Moon, and Planets, 30, 149-173, 1984.

Neukum, G., and K. Hiller, Martian ages, J. Geophys. Res., 86, $3097-$ $3121,1981$.

Neukum, G., and D. U. Wise, Mars: A standard crater curve and possible new time scale, Science, 194, 1381-1387, 1976.

Neukum, G., B. Konig, and J. Arkani-Hamed, A study of lunar impact crater size-distributions, The Moon, 12, 201-229, 1975.

Pechmann, J. C., The origin of polygonal troughs on the northern plains of Mars, Icarus, 42, 185-210, 1980.

Pieri, D., Distribution of small channels on the Martian surface, Icarus, $27,25-50,1976$

Plescia, J. B., and R. S. Saunders, The chronology of the Martian volcanoes, Proc. Lunar Planet. Sci. Conf. 10th, 2841-2859, 1979.

Plescia, J. B., and R. S. Saunders, Tectonic history of the Tharsis region, Mars, J. Geophys. Res., 87, 9775-9791, 1982.

Pollack, J. B., D. S. Colburn, F. M. Flasar, R. Kahn, C. E. Carlston, and D. Pidek, Properties and effects of dust particles suspended in the Martian atmosphere, J. Geophys. Res., 84, 2929-2945, 1979.

Roth, L. E., G. S. Downs, R. S. Saunders, and G. Schubert, Radar altimetry of south Tharsis, Mars, Icarus, 42, 287-316, 1980.

Schaber, G. G., Syrtis Major: A low-relief volcanic shield, J. Geophys. Res., 87, 9852-9866, 1982.

Schaber, G. G., K. C. Horstman, and A. L. Dial, Jr., Lava flow materials in the Tharsis region of Mars, Proc. Lunar Planet. Sci. Conf. 9th, 3433-3458, 1978.

Schultz, P. H., and A. B. Lutz-Garihan, Ancient polar locations on Mars: Evidence and implications (abstract), in Papers Presented to the Third International Colloquium on Mars, pp. 229-231, Lunar and Planetary Institute, Houston, 1981.

Schultz, P. H., R. A. Schultz, and J. Rogers, The structure and evolution of ancient impact basins on Mars, J. Geophys. Res., 87, 9803-9820, 1982.

Scott, D. H., Geologic problems in the northern plains of Mars, Proc. Lunar Planet. Sci. Conf. 10th, 3039-3054, 1979.

Scott, D. H., Volcanoes and volcanic provinces: Martian western hemisphere, J. Geophys. Res., 87, 9839-9851, 1982.

Scott, D. H., and M. H. Carr, Geologic map of Mars, Misc. Invest. Ser. Map I-1083, U. S. Geol. Surv., Reston, 1978.

Scott, D. H., and J. S. King, Ancient surfaces of Mars: The basement complex (abstract), in Lumar and Planetary Science $X V$, pp. 736737, Lunar and Planetary Institute, Houston, 1984.

Scott, D. H., and K. L. Tanaka, Mars: A large highland voleanic province revealed by Viking images, Proc. Lunar Planet. Sci. 12B, 1449-1458, $1981 a$.

Scott, D. H., and K. L. Tanaka, Paleostratigraphic restoration of buried surfaces in Tharsis Montes, Icarus, 45, 304-319, $1981 b$.

Scott, D. H., and K. L. Tanaka, Ignimbrites of Amazonis Planitia region of Mars, J. Geophys. Res., 87, 1179-1190, 1982.

Scott, D. H., and K. L. Tanaka, Preliminary geologic map of the western equatorial region of Mars: Part A, Open-File Report 84-659-A, U. S. Geol. Surv., Reston, 1984.

Scott, D. H., and K. L. Tanaka, Geologic map of the western equatorial region of Mars, Misc. Invest. Ser. Map I-1802-A, U. S. Geol. Surv., Reston, 1986

Scott, D. H., G. G. Schaber, K. L. Tanaka, K. C. Horstman, and A. L. Dial, $\mathfrak{J}_{\text {r., }}$ Map series showing lava-flow fronts in the Tharsis region of Mars, Misc. Invest. Ser. Maps I-1266 to I-1280, U. S. Geol. Surv., Reston, 1981.

Sharp, R. P., and M. C. Malin, Channels on Mars, Geol. Soc. Amer. Bull., 86, 593-609, 1975.

Sjogren, W. L., Mars gravity: High-resolution results from Viking Orbiter 2, Science, 203, 1006-1010, 1979.

Soderblom, L. A., C. D. Condit, R. A. West, B. M. Herman, and T. J. Kriedler, Martian planetwide crater distributions: Implications for geologic history and surface processes, Icarus, 22, 239-263, 1974. 
Squyres, S. W., Martian fretted terrain: Flow of erosional debris, Icarus, 34, 600-613, 1978.

Squyres, S. W., The evolution of dust deposits in the Martian north polar region, Icarus, 40, 244-261, 1979.

Strom, R. G., Mercury: A post-Mariner 10 assessment, Space Sci. Rev., $24,3-70,1979$.

Strom, R. G., and E. A. Whitaker, Populations of impacting bodies in the inner Solar System, Reports of Accomplishments of Planetology Programs, 1975-1976, pp. 194-196, NASA TM X-3364, 1976.

Tanaka, K. L., A new time-saving crater-count technique, with application to narrow features (abstract), Reports on Planetary Geology Program-1982, pp. 123-125, NASA TM 85127, 1982.

Tanaka, K. L., Probable lack of very ancient terrain on Mars revealed by crater-population comparisons with the Moon (abstract), in Lunar and Planetary Science $X V$, pp. 844-845, Lunar and Planetary Institute, Houston, 1984.

Tanaka, K. L., Crater-density stratigraphy of the western Martian highlands (abstract), in Lunar and Planetary Science XVI, pp. 843844, Lunar and Planetary Institute, Houston, 1985a.

Tanaka, K. L., Ice-lubricated gravity spreading of the Olympus Mons aureole deposits, Icarus, 62, 191-206, 1985b.

Tanaka, K. L., New stratigraphic developments for Mars (abstract), in Lunar and Planetary Science XVI, pp. 845-846, Lunar and Planetary Institute, Houston, $1985 c$.

Tanaka, K. L., and D. H. Scott, Channels of Mars' Elysium region: Extent, sources, and stratigraphy (abstract), Reports of Planetary Geology and Geophysics Program-1985, pp. 403-405, NASA TM 88383, 1986.

Tanaka, K. L., and D. H. Scott, Geologic maps of the polar regions of Mars, Misc. Invest. Ser. Map 1-1802-C, U. S. Geol. Surv., Reston, in press, 1987.

Tsoar, H., R. Greeley, and A. R. Peterfreund, Mars: The north polar sand sea and related wind patterns, J. Geophys. Res., 84, 8167-8182, 1979.
U. S. Geological Survey, Shaded relief maps of the eastern, western and polar regions of Mars, Misc. Invest. Ser. Map I-1618, U. S, Geol. Surv., Reston, 1985.

Wichman, R., and P. H. Schultz, Timing of ancient extensional tectonic features on Mars (abstract), in Lunar and Planetary Science XVII, pp. 942-943, Lunar and Planetary Institute, Houston, 1986.

Wilhelms, D. E., Stratigraphy of part of the lunar near side, $U . S$. Geol. Surv. Prof. Pap. 1046-A, 71 pp., 1980.

Wilhelms, D. E., Geologic history of the Moon, U. S. Geol. Surv Professional Paper 1348, in press, 1986.

Wilhelms, D. E., V. R. Oberbeck, and H. R. Aggarwal, Size-frequency distributions of primary and secondary lunar impact craters, Proc. Lunar Planet. Sci. Conf. 9th, 3735-3762, 1978.

Wise, D. U., Geologic map of the Arcadia quadrangle of Mars, Misc. Invest. Ser. Map 1-1154, U. S. Geol. Surv., Reston, 1979.

Wise, D. U., M. P. Golombek, and G. E. McGill, Tectonic evolution of Mars, J. Geophys. Res., 84, 7934-7939, 1979.

Witbeck, N. E., and J. R. Underwood, Jr., Geologic map of the Mare Acidalium quadrangle, Mars (revised), Misc. Invest. Ser. Map 1-1614, U. S. Geol. Surv., Reston, 1984.

Woronow, A., A size-frequency study of large Martian craters, $J$. Geophys. Res., 82, 5807-5820, 1977.

Wu, S. S. C., R. Jordan, and F. J. Schafer, Mars global topographic map: 1:15,000,000-scale, Reports of Planetary Geology and Geophysics Program-1985, pp. 614-617, NASA TM 88383, 1986.

Kenneth L. Tanaka, U. S. Geological Survey, 2255 N. Gemini $D_{r}$, Flagstaff, AZ 86001.

(Received April 30, 1986;

revised August 22, 1986;

accepted August 22, 1986.) 